S. Department of Transportation

Federal Highway Administration

\title{
Meeting the Customer's Needs for Mobility and Safety During Construction and Maintenance Operations
}

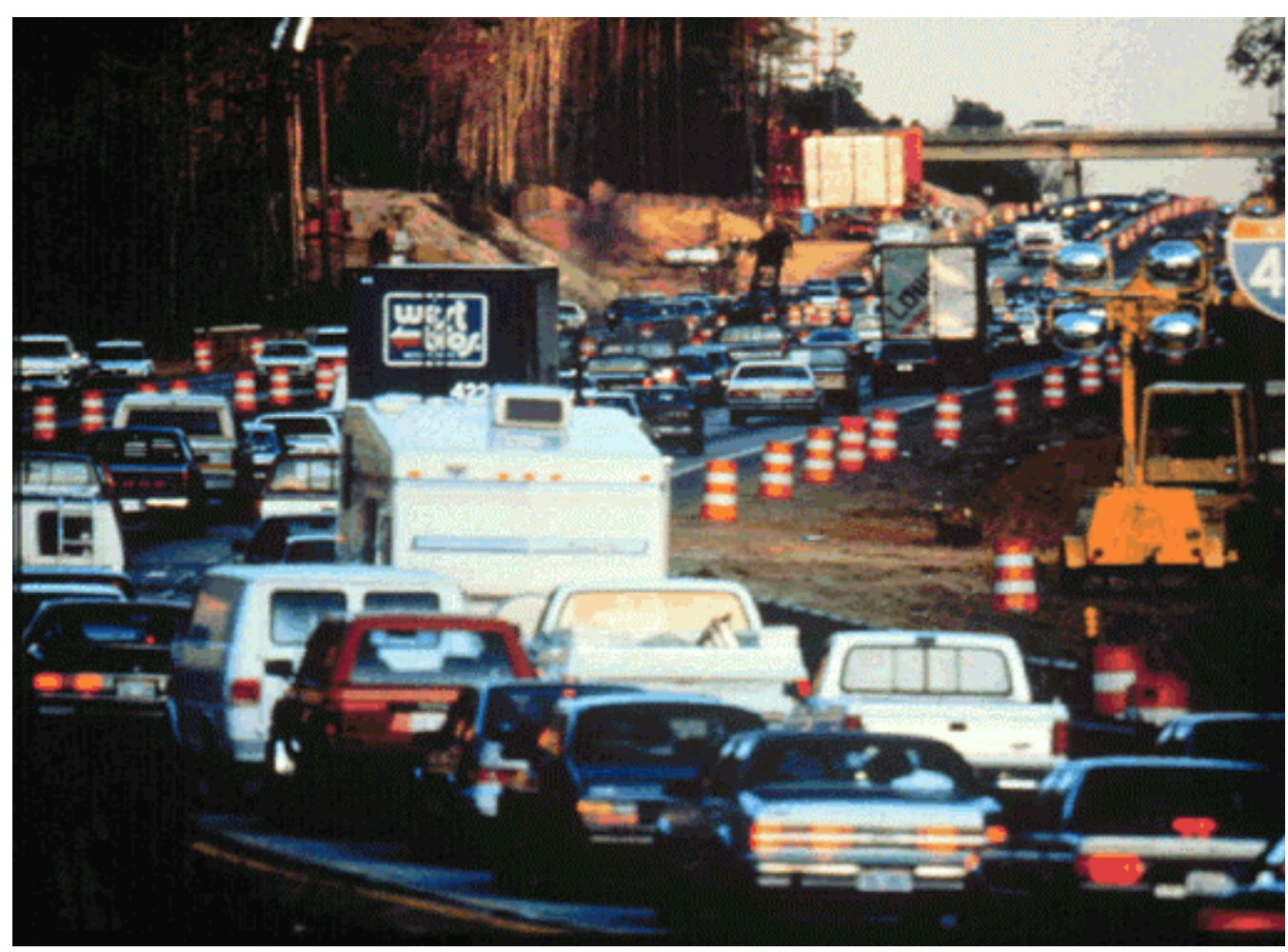

Office of Program Quality Coordination

September 1998 HPQ - 98 - 1 


\section{Notice}

This document is disseminated under the sponsorship of the Department of Transportation in the interest of information exchange. The United States Government assumes no liability for its contents or use thereof.

The contents of this report reflect the views of the authors, who are responsible for the facts and accuracy of the data presented herein. The contents do not necessarily reflect the official policy of the Department of Transportation.

This report does not constitute a standard, specification, or regulation.

The United States Government does not endorse products or manufactures. Trademarks or manufactures' names appear herein only because they are considered essential to the object of this document. 


\section{Meeting the Customer's Needs for Mobility and Safety During \\ Construction and Maintenance Operations}

\section{TABLE OF CONTENTS}

\section{INTRODUCTION}

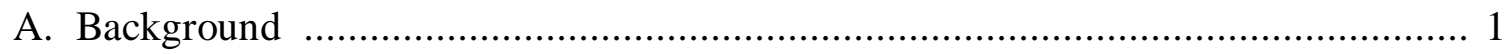

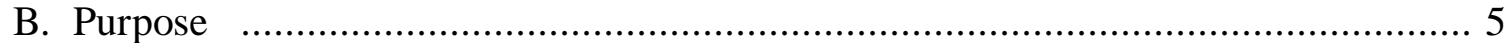
C. Specific Objectives $\quad$.................................................................................. 5

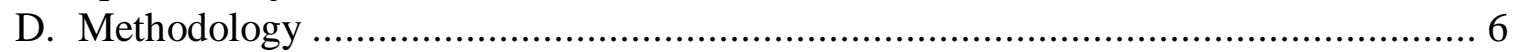
E. Review Team …................................................................................... 7

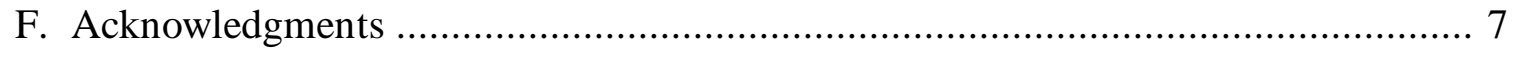

\section{OBSERVATIONS, COMMENTS AND RECOMMENDATIONS}

A. Preliminary Assessments ...................................................................... 9

B. State of the Practice - Reducing delays and enhancing safety in work zones ........ 15

C. State of the Art - Reducing delays and enhancing safety in work zones .............. 25

D. FHWA's Leadership Role in reducing delays and enhancing safety in work zones 35

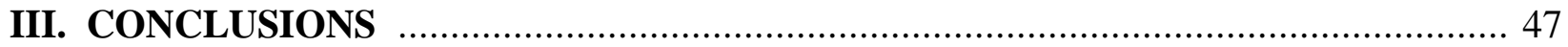

IV. SUMMARY OF RECOMMENDATIONS .................................................. 49

V. APPENDICES

A. Best Policies/Practices identified by the Transportation Agencies included in the review to minimize delay and enhance safety during construction and maintenance operations

B. Transportation Agencies, Associations, Organizations and Industries Participating in the Review

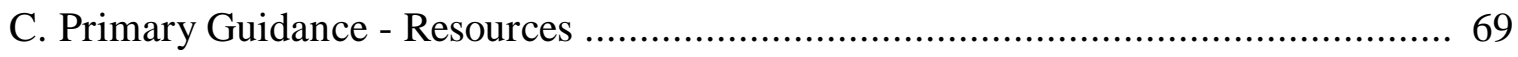

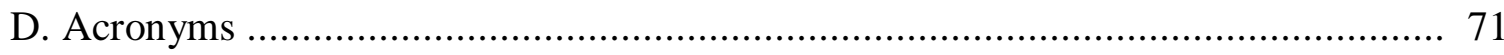




\section{INTRODUCTION:}

\section{A. Background}

The safe and efficient flow of traffic through construction and maintenance work zones is a major concern to transportation officials, the highway industry, the traveling public, and the Congress. Today the majority of highway funds are being used on system preservation (resurfacing, restoration, rehabilitation, and reconstruction) type projects on the existing highway system. America's traveling public is demanding virtually unlimited mobility, and congestion has a significant effect on their mobility. Mobility and safety are closely tied together. As congestion builds, crash rates increase and as crashes increase there is more congestion. In addition to the safety of the traveling public and highway workers, motorists are delayed when they are not able to travel at the normal operating speed through a work zone.

In 1993, the total cost of congestion in our nation's 50 largest metropolitan areas was approximately $\$ 51$ billion, a 6 percent increase in the 1992 congestion cost of $\$ 48$ billion. The 1993 average per capita cost of congestion in these 50 largest metropolitan areas was $\$ 370$.

While national data on the cost of work zone delays is not readily available, daily road user delay costs on many urban freeway reconstruction projects have been calculated to be over $\$ 50,000$ per day. When the magnitude of this figure is projected on a national scale, delay costs in work zones are staggering.

Work zone fatalities rose to an all time high of 833 in 1994. While the number of fatalities in work zones has declined each year since then, the 771 fatalities in 1995, and 719 fatalities in $1996^{2}$ are still a major concern and point out the need for continuous emphasis on work zone safety. Approximately 55 percent of work zone fatalities occur in rural areas. ${ }^{3}$ Twenty-five percent of the 719 work zone fatalities in 1996 involved large trucks. ${ }^{2}$ Despite these alarming statistics, as noted in Section II D, inconsistencies in defining and reporting work zone crashes make the problem much worse than indicated by the above numbers. The fatality rate for highway construction workers is twice the rate for other types of construction. In 1996, 133 highway workers were killed in work zones (125 in 1995). Approximately 35 percent of these highway worker fatalities were directly related to traffic moving through the work zone. ${ }^{4}$

${ }^{1}$ Urban Roadway Congestion - 1982-1993 Annual Report, Research Report 1131-8, Texas Transportation Institute - August 1996

${ }^{2}$ Fatal Analysis Reporting System maintained by the National Highway Traffic Safety Administration

${ }^{3}$ Compiled from tables in the 1994 Highway Statistics, Federal Highway Administration October 1995

${ }^{4}$ Laborers' Health and Safety Fund of North America 
In addition to these fatalities, there were approximately 37,000 injuries in work zones that resulted from motor vehicle crashes in $1996 .{ }^{5}$

The demands for rehabilitating highways, increased mobility, and safety have resulted in many more highway projects being constructed at night adjacent to high speed traffic. These factors significantly increase the exposure of the traveling public, highway workers, and pedestrians to work zone hazards.

Congress expressed concern about work zone safety in Section 1051 of the Intermodal Surface Transportation Efficiency Act (ISTEA) of 1991, by requiring the Secretary of Transportation to develop and implement a work zone safety program which would "... improve work zone safety at highway construction sites by enhancing the quality and effectiveness of traffic control devices, safety appurtenances, traffic control plans, and bidding practices for traffic control devices and services." The Federal Highway Administration (FHWA) published the National Highway Work Zone Safety Program (NHWZSP) in the October 24, 1995, Federal Register. The NHWZSP is the structure the FHWA will follow in planning, developing, implementing, and monitoring work zone safety and operational activities nationally. The objective of the NHWZSP is to enhance the safety and operational efficiency of highway work zones for all road users (motorists, pedestrians, motorcyclists, bicyclists), and highway workers. It is applicable to all public highways and streets with early implementation emphasis on the National Highway System (NHS). The NHWZSP is intended to be a model for State and local governments to follow in developing or revising their own work zone improvement programs. The Congress placed additional emphasis on work zone safety in Section 358(b) of the National Highway System Designation Act of 1995, by requiring the Secretary of Transportation to utilize a variety of methods to increase safety at highway construction sites.

Section 1090 of the ISTEA required the Secretary of Transportation to perform a study and report to Congress on methods of enhancing traffic flow and minimizing traffic congestion during construction of Federal-aid highway projects and on costs associated with implementing such methods. In mandating this study and report, Congress stated "It is the sense of Congress that many highway projects are carried out in a way which unnecessarily disrupts traffic flow during construction and that methods need to be adopted to eliminate or reduce these disruptions." In submitting the report which was sent to Congress on October 26, 1992, the FHWA assured Congress that current activities promote work zone safety and minimize disruptions to traffic during construction. Additionally, the FHWA offered the following recommendations to assure continued improvement in the Agency's efforts to alleviate congestion caused by construction:

1. The FHWA should continue to emphasize and promote the philosophy of minimizing construction interference with traffic while ensuring safety through its routine activities and in all work zone-related training efforts.

${ }^{5}$ General Estimates System maintained by the National Highway Traffic Safety Administration. 
2. The FHWA should continue to encourage research in innovative methods to reduce traffic congestion during construction.

3. The FHWA should continue to provide technical assistance to the State Highway Agencies in developing and implementing programs which promote effective construction traffic management.

Representatives of industry, State transportation officials, and the FHWA met in November 1992, and established a national initiative to promote the quality of our highway system. This "National Quality Initiative" (NQI) represents a major commitment to promote the partnership of all entities that participate in the funding, design, and construction of our highways. In 1995, NQI sponsored a survey of the driving public to measure satisfaction with the nation's highways. The survey asked each respondent to assess the following seven characteristics of the highway system:

$\begin{array}{ll}\text { C } & \text { Bridge Conditions } \\ \text { C } & \text { Maintenance Response Time } \\ \text { C } & \text { Pavement Conditions } \\ \text { C } & \text { Safety } \\ \text { C } & \text { Traffic Amenities } \\ \text { C } & \text { Traffic Flow } \\ \text { C } & \text { Visual Appeal }\end{array}$

The 2,205 participants ranked their stated priorities for improvement as follows:

$\begin{array}{ll}\text { C } & \text { Safety } \\ \text { C } & \text { Pavement Conditions } \\ \text { C } & \text { Traffic Flow }\end{array}$

Only 29 percent of the survey respondents were satisfied with the traffic flow through work zones. They said, "Don't just do temporary repairs but repair the road permanently" and "They should work on highways at night when there is no traffic." The survey clearly shows that the public's top priority for improving the nation's highways is for the highway industry/community to focus on the quality of the road surface. However, they expect these improvements to the road surface to be done safely and without restricting the flow of traffic through the work zone.

The safe and efficient flow of traffic through work zones has been, and continues to be, a major concern to the transportation community. On September 28 through October 1, 1986, the Transportation Research Board (TRB) held a national conference on "Corridor Traffic Management for Major Highway Reconstruction" in Chicago, Illinois. Representatives from the FHWA, more than 30 State transportation agencies, several cities, regional planning agencies, contractors, and consultants attended this conference which was sponsored by the FHWA. The proceedings of this national conference were published in TRB Special Report 212. 
In addition to this national programmatic review by the FHWA's Office of Program Quality Coordination (OPQC), there are a number of other national initiatives that have been completed or are in progress to address safety and delays in work zones. Some of the major initiatives the OPEC Review Team (hereafter referred to as the Review Team) are aware of include:

C Customer Oriented Highway Construction Workshop to Improve Safety, Reduce Delay, and Minimize Disruption in Highway Construction and Maintenance Areas, sponsored by the National Asphalt Paving Association and FHWA; October 13-14, 1997.

C Highway Work Zone Safety: New Methods and Technologies Conference, sponsored by the Laborers' International Union of North America, Laborers' Health and Safety Fund of North America, and Johns Hopkins University; October 28-29, 1997.

C Joint Committee Resolution JCR-1-97,"Issues Involving Delays in Completing FederalAid Highway and Bridge Projects," approved by the American Association of State Highway and Transportation Officials (AASHTO), the Association of General Contractors (AGC), and the American Road and Transportation Builders Association; October 30, 1997.

C User Conference - Highway Closure and Restriction System, sponsored by the Arizona Department of Transportation; December 4-5, 1997.

C Urban Expressway Pavement Renewal Workshop, sponsored by the Transportation Research Board, California Department of Transportation, and the FHWA; February 16-19, 1998.

C 1998 Symposium on Innovative Contracting, sponsored by the FHWA; April 14-15, 1998.

C Primer on Contracting 2000 - A draft report of the Contract Administration Task Force of the AASHTO Subcommittee on Construction; 1997.

C National Work Zone Safety Information Clearinghouse - The clearinghouse is supported by a joint AASHTO/ARTBA/AGC subcommittee on work zone safety.

C Program Initiative Optimizing Highway Performance - Meeting the Customers' Demands, FHWA, Office of Engineering, Highway Operations Division; in progress.

C Illinois DOT's Roundtables on Construction Methods and Materials; April 1998, Corridor Planning and Management; summer 1998, Project Development Process; winter 1998-1999, and Public Outreach; winter 1998-1999.

C National Cooperative Highway Research Program Synthesis - Project Development Methodologies for Reconstruction of Urban Freeways and Expressways; in progress. 
As traffic volumes increase and our nation's highway system matures, congestion, delays, fatalities, injuries, and property damage crashes will also increase unless the entire transportation community rallies to meet this challenge! The FHWA has accepted this challenge of significantly reducing the needless loss of human life, time, and money in work zones and urges others to partner in this effort.

\section{B. Purpose}

The purpose of this quality improvement review was to assess the effectiveness of the FHWA's and State DOT's policies and procedures in enhancing safety, improving mobility, and increasing the efficiency of the NHS by reducing traffic congestion/delays during construction and maintenance operations.

\section{Specific Objectives of the Review}

C Establish an organizational baseline of FHWA's leadership role in reducing motorist delays and enhancing the safety of work zones.

C Evaluate the effectiveness of the practices/policies being used by the States to measure, evaluate, and enhance the flow of traffic in work zones.

C Identifying the best practices/policies currently being used by the States to enhance the flow of traffic or to accelerate the progress of work in work zones to minimize the exposure to drivers and highway workers.

C Identify effective models for evaluating the effects (risk, cost, and duration) of lane closures and reduced standards in the work zone.

C Identify effective models for balancing road-user cost against the additional cost, if any, to a State DOT's budget for accelerating the progress of work.

C Identify the specific activities FHWA field offices have taken to implement the recommendations in the September 1992 Report to Congress on "Traffic/Congestion Management During Highway Construction." (Section 1090 of ISTEA.)

C Identify the specific activities field offices have taken to implement the NHWZSP published in the Federal Register of October 24, 1995.

C Identify any impediments to States taking advantage of innovative contracting, innovative construction procedures, high-performance materials, and/or practices to accelerate the progress of work.

C Identify the value-added activities the division and region offices currently perform to enhance safety and reduce traffic congestion in work zones. 
C Develop a traffic management model program for reducing traffic congestion, minimizing delays, and enhancing the safety in work zones that can be used by the division and region offices for process improvement and benchmarking.

C Identifying any assistance or research needed from FHWA Headquarters and region offices to improve the State and division office activities to enhance safety and reduce traffic congestion in work zones.

\section{Methodology}

A two-step process was used by the Review Team in conducting this review: (1) completion of a Baseline Assessment Data Form by all FHWA field offices, and (2) a scan of selected States. The Executive Director's November 26, 1997, memorandum transmitted Baseline Assessment Data Forms to all FHWA field offices. The purpose of these Baseline Assessment Forms was to provide FHWA's field offices with a tool to evaluate their past actions, reduce congestion, reduce delays, enhance safety in work zones, and establish a baseline of their current state of practice. The completed Baseline Assessment Forms also provided the Review Team with the data needed to establish a generic organizational baseline of FHWA's leadership role, as well as identify the best practices/policies currently being used to minimize congestion, reduce motorist delays, and enhance safety in work zones. During the scanning portion of the review, the Review Team visited some of the States that best exemplified the identified best practices/policies. A representative from several Headquarters program offices was invited and the FHWA region office was encouraged to accompany the Review Team during the visits in their respective region. The Review Team met with FHWA division office personnel, as well as, top level State DOT management and staff in 26 States in the 9 FHWA regions. These discussions provided the divisions, regions, and State DOTs with an opportunity to share more detailed information on their most effective practices/policies and to provide input on ways the FHWA can enhance traffic flow and reduce traffic congestion in work zones. In addition, the Review Team met with senior managers representing large city and county highway departments, toll authorities, State contractor associations, equipment manufactures/suppliers, trucking and automobile associations, and highway advocacy groups in several States. The information gained from the completed Baseline Assessment Forms and site visits was used to establish a traffic management model that can be used by the field offices for process improvement and benchmarking. This information, assembled during the review, will be used as input to the Headquarters program offices to develop long-term program initiatives. This review was limited to the Federal-aid program; however, the results of this review are also applicable to the FHWA's Federal Lands Highway Office and, indeed, all highway system preservation projects.

The scanning portion of the review consisted of visiting the following States between January 26, 1998 and June 11, 1998. 


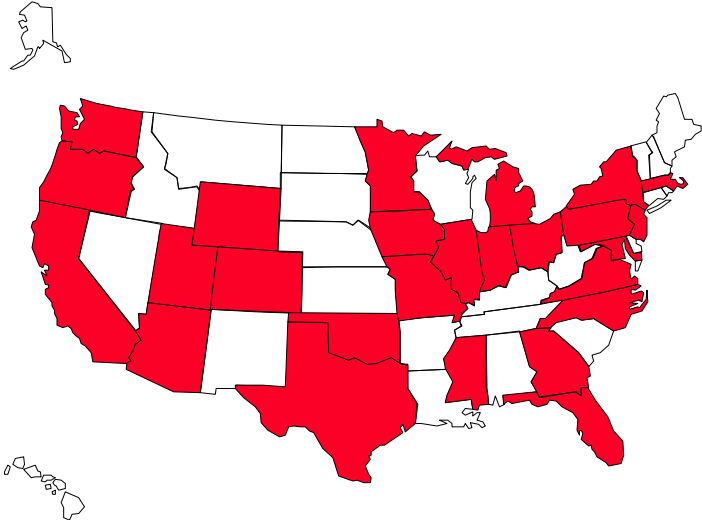

\section{E. Review Team}

The core Review Team consisted of:

Daniel M. Mathis, P.E. Assistant Division Administrator Illinois Division Springfield, Illinois
James B. Sorenson Senior Engineer Office of Engineering Washington, DC

$\begin{array}{lll}\text { Arizona } & \text { Massachusetts } & \text { Oklahoma } \\ \text { California } & \text { Minnesota } & \text { Oregon } \\ \text { Colorado } & \text { Michigan } & \text { Pennsylvania } \\ \text { Florida } & \text { Mississippi } & \text { Texas } \\ \text { Georgia } & \text { Missouri } & \text { Utah } \\ \text { Illinois } & \text { New Jersey } & \text { Virginia } \\ \text { Indiana } & \text { New York } & \text { Washington } \\ \text { Iowa } & \text { North Carolina } & \text { Wyoming } \\ \text { Maryland } & \text { Ohio } & \end{array}$

Arizona Massachusetts Oklahoma

California

Michigan

Oregon

Pennsylvania

Texas

Virginia

Washington

North Carolina Wyoming

Ohio

Other Headquarters program offices assisted the core team by the following individuals participating in the visits to one or more of the States included in the scanning portion of the review:
Brian Gilleran - HHS-22
Paul Harker - HHS-10
Jon Obenberger - HTV-31
Rudy Ramirez - HHS-22
Michael Robinson - HHS-21
Charles Sears - HNG-21
Edward A. Terry, Jr., P.E. Engineering Specialist Office of Program Quality Coordination Washington, DC

In addition, a representative from each of the FHWA region offices accompanied the Review Team during the visits to their respective region.

\section{F. Acknowledgments}

The Review Team would like to thank all of the individuals from the 115 transportation agencies, associations, organizations, and industries for their active participation in this review. Without their candid opinions and helpful suggestions, this review would not have been a success. Dedicated and knowledgeable individuals are present and are making a difference in each of 26 States included in the review. The Review Team was impressed by the enthusiasm and the desire of the transportation community to cooperatively work together in order to significantly reduce work zone delays and crashes. A list of all of the transportation agencies, associations, organizations and industries, outside of the FHWA, participating in the review is included in Appendix B. 



\section{OBSERVATIONS, COMMENTS, AND RECOMMENDATIONS}

\section{A. Preliminary Assessments}

In assembling the background data for this review, the Review Team was not able to locate any studies that had quantified the amount of delay experienced by motorists on an area-wide, Statewide, or national basis. Nor was the Review Team able to find any quantified data on regional or national economic losses due to work zones. A review of the of work zone fatality data ${ }^{6}$ revealed that the total number of fatalities in work zones have remained fairly constant since 1980.

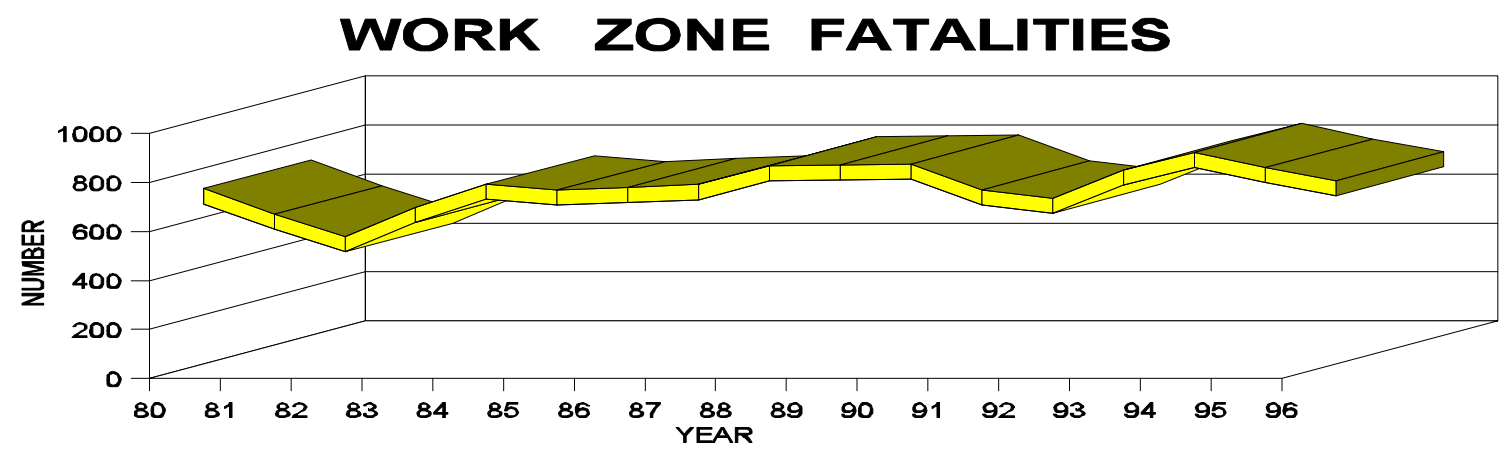

\begin{tabular}{|c|c|c|c|c|c|c|c|c|c|c|c|c|c|c|c|c|c|}
\hline YEAR & 80 & 81 & 82 & 83 & 84 & 85 & 86 & 87 & 88 & 89 & 90 & 91 & 92 & 93 & 94 & 95 & 96 \\
\hline $\begin{array}{c}\text { NUMBER } \\
\text { OF } \\
\text { FATALITIES }\end{array}$ & 685 & 580 & 489 & 609 & 703 & 679 & 691 & 702 & 780 & 782 & 786 & 680 & 647 & 762 & 833 & 771 & 719 \\
\hline
\end{tabular}

The Review Team was forced to use the total number of fatalities in work zones as a measure since no studies were identified which calculated fatality rates. While the total number of fatalities in work zones have remained fairly constant, it is recognized that traffic volumes have risen, the highway system has aged, the predominant type of work has shifted from new construction on new alignments to system preservation type work which is done under traffic, and the dollar amount available for highway construction has increased since 1980. All of these factors have increased the number of work zones since 1980. On the other hand, as noted in Section II D, the actual number of work zone fatalities are much higher than the number of work zone fatalities reported in the Fatal Analysis Reporting System (FARS) data. Since previous focus and efforts have not significantly reduced the total number of work zone fatalities, it is reasonable to assume that, with the substantial increase in funding levels provided in the Transportation Equity Act for the 21st Century (TEA-21) coupled with the steady growth of traffic volumes and our aging highway system, the number of work zones will increase sharply in the coming years with the potential for increased fatalities unless a significantly

${ }^{6}$ Data from the Fatal Analysis Reporting System maintained by the National Highway Transportation Safety Administration. 
different approach is taken to address work zone safety. Therefore, the Review Team concluded that this review should be focused on reducing the exposure of the motorist/highway worker, and that the FHWA's future efforts to meet our customer's needs for mobility and safety during construction and maintenance operations should be centered on traffic management principles.

Work zone traffic management is not a separate program nor is work zone traffic management a new concept. Work zone traffic management is much more than traffic control in the work zone; it is a broad umbrella approach that involves long-range strategies for moving people and goods safely and efficiently through a traffic corridor. Traffic management is driven by a transportation agency's mission to meet their customer's needs for mobility and safety.

Traffic management applied to construction and maintenance operations involves a comprehensive series of actions designed to minimize motorist delays while enhancing the safety of the motorist and the highway worker. These actions span the entire life of a project; beginning in the early project planning phase and continuing through programming, design, construction, operations, and maintenance. Work zone traffic management encompasses most of our current areas of emphasis; safety, mobility, quality, team work, customer focus, asset management, intermodalism, Intelligent Transportation Systems (ITS), technology transfer, longer lasting materials, performance-based specifications, innovative contracting, life-cycle costing, motorist information, and incident management.

The objective of traffic management is the development and implementation of an overall strategy which allows construction and maintenance operations to be completed safely with a minimum impact on the motorist, the highway worker, and the adjacent residential/business communities.

The key to minimizing motorist delays during construction and maintenance operations is recognizing the impacts that the proposed work can have on traffic and/or adjacent residents and businesses in sufficient time to develop and implement the appropriate cost effective mitigative measures prior to the delays occurring. Traffic management in the work zone is proactive as opposed to reactive.

While the principles of traffic management apply to all construction and maintenance operations, traffic management is not a "one size fits all" approach. Obviously, the degree and extent of the techniques needed to mitigate the effects of a construction or maintenance operation vary from project to project and will depend upon the location, traffic demand volumes, and available capacity.

Motorist delay and safety are closely tied together; crashes cause congestion and congestion causes crashes. By reducing the exposure of the motorist in work zones, the number of crashes, disabling injuries, and fatalities in work zones are reduced. Additionally, highway workers and inspection personnel are provided with a safer work environment. Therefore, successful traffic management depends upon reducing the exposure rates in work zones by: 
(1) Reducing the volume of traffic through the work zone:

Traffic volumes can be reduced by closing the facility, diverting traffic to other routes, modes, ride sharing, and/or spreading the peak hourly volumes out over a longer period of time by changing travel times (flextime, alternate work schedules, etc.). For any of these techniques to be successful the motorist must be provided with accurate information in sufficient time to make an informed decision. Several States have experienced a 20 to 25 percent reduction in peak hour traffic volumes during the reconstruction of large metropolitan freeway projects.

"The key to reducing traffic volumes in work zones is advanced publicity." .... State DOT Official

(2) Reducing the length of time that work zones are in place:

The length of time that work zones are in place can be reduced by using the critical path method (CPM) to establish, manage, and monitor contract time. The use of time-based bidding ( $\mathrm{A}+\mathrm{B}$ Bidding, lane rental, and incentives for early completion), and variable start dates or "window" specifications have also proven effective in significantly reducing contract times. Dividing larger projects into usable segments or phases that can be completed in one construction season has been effective in many areas. Exposure rates are also reduced by breaking the project length into shorter segments and having the contractor concentrate their efforts in shorter segments before opening additional segments.

"A + B has help reduce the amount of time immensely." .... State DOT Official

The length of time that work zones are in place can also be significantly reduced through an effective preventive maintenance program. Preventive maintenance operations can be completed in much shorter time frames and are much less disruptive than rehabilitation/reconstruction projects.

(3) Reducing the frequency that work zones are established:

Of the three ways, the greatest potential for reducing the exposure of the highway user/worker is by reducing the frequency that work zones are established. The number of work zones can be significantly reduced by making our products last longer. This is accomplished by improved designs; using longer lasting materials, performance-based specifications, and warranties; and most importantly emphasizing "attention to details" during the construction and maintenance operations, i.e., "Do it right the first time." 
The life of a bituminous overlay varies from State to State, but the national average ranges from 6 to 16 years. If 10 years is used as the national average life of a bituminous overlay, by definition 10 percent of all bituminous pavements undergo a construction or maintenance operation each year. However, if the life of a bituminous overlay was extended to 20 years, one-half of the number of miles overlaid each year would be eliminated! Similarly, if we consider a $100 \mathrm{~km}$ section of highway and if it takes 2 construction seasons to reconstruct a $10 \mathrm{~km}$ segment of that highway and it lasts for 20 years, by the time the last section is finished, the first section will need to be rehabilitated again. In other words, we will never finish the reconstructing projects on that $100 \mathrm{~km}$ section of highway. The traveling public would experience a work zone on this stretch of highway for the rest of their lives!

"We expect Superpave overlays to last $20 \%$ longer than other overlays." FHWA Official

The life of the highway can be significantly increased by practicing preventive maintenance techniques, i.e., performing the right work at the right time. This increase in life results in reduced cost and disruption to the road users.

The number of work zones can also be reduced through a corridor approach as opposed to a project-by-project approach. The corridor approach to traffic management during construction and maintenance operations utilizes all available routes and modes to move traffic through the traffic corridor. The corridor approach also includes identifying all identifiable long-range (+/- 30 to 50 years) needs, pavement, bridge, safety, and traffic operations, preventive maintenance, as well as, rehabilitation in a traffic corridor. Projects are then sequenced and packaged in a way that minimizes the inconvenience to the traveling public.

Successful traffic management depends upon continuous coordination, communication, and cooperation of highway officials, the construction team (owner, contractor, and designer) the motorist, elected officials, police, the media, as well as, the affected residential, and business communities.

The Review Team identified several stages and essential elements in a successful traffic management program that take place throughout the life of a project. These stages and elements were used to describe the State of the Art (Section II C) and to categorize the Best Practices/Policies (Appendix A).

C Policy/Direction/Standard Operating Procedures,

C Public Relations/Education/Outreach (General Public, Drivers, Policy Makers, and Elected Officials),

C Prediction Modeling and Impact Analysis: Congestion and Crashes,

C Planning and Programming, 


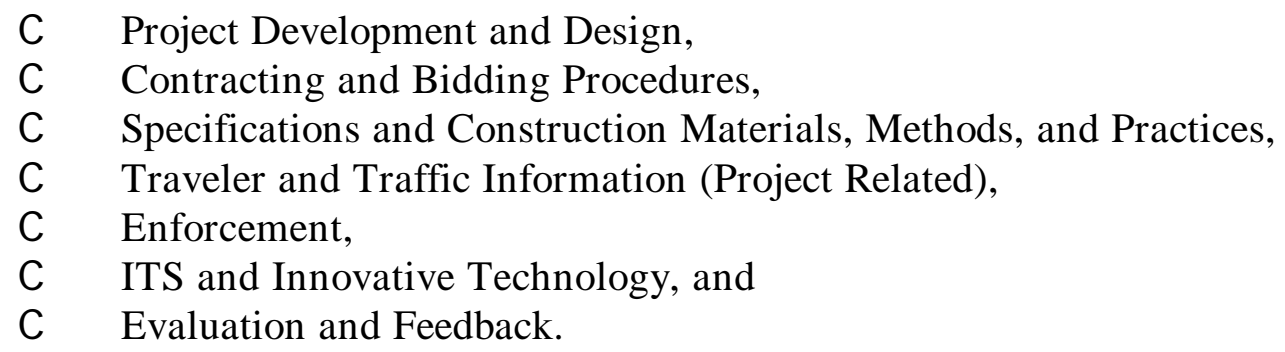

Effective work zone traffic management is a continuous series of acts aimed at balancing safety, motorist delay/cost, project cost, quality of the work, and time to complete the project. However, the good news is that these items (safety, cost, time, and road-user benefits) are not mutually exclusive! 



\section{B. State of the Practice - Reducing Delays and Enhancing Safety in Work Zones}

\section{OBSERVATION: Most senior State and local transportation officials are keenly aware of the delays and economic impacts caused by work zones, but their philosophy has not been formally documented in policy statements and/or performance goals; nor is this awareness ingrained in the culture of the Agency.}

None of the States included in the scanning portion of this review have quantified the amount or cost of work zone delays on an area-wide or Statewide basis. However, senior State and local transportation officials are keenly aware of the delay and economic impacts caused by work zones. While top management's awareness and desire has been put into practice, on a limited number of highly visible projects, their philosophy has not been translated into policy statements/ performance goals nor has it filtered down through the organizations to the point that it impacts all construction and maintenance operations.

In recent years, transportation officials have taken a harder look at delays and the economic impact of work zones on road users and the business community. Without exception, Toll Authority officials told the Review Team that they decide on the best way to manage the traffic before they begin the detail design needed to correct highway deficiencies. City highway officials told the Review Team that their first concern is the impact to the residential and business communities affected by the project. This approach, designing the work around the customer's needs for mobility, is radically different. While this change has started and is beginning to take hold in several State DOTs, it is not ingrained in the culture of most highway agencies.

"Traffic control drives the design as well as drives the material selection." .... Toll Authority Official

\section{OBSERVATION: All of the State and local transportation agencies recognize that} completing the work safely is of utmost importance.

Work zone safety has been a concern of transportation officials for a number of years, but work zone safety has seldom driven the process. Many times the project cost and urgency to complete the work has taken precedence.

This situation is due in part to the lack of good work zone crash data (rates and severity), as well as the cost effectiveness of differing traffic control devices

"My primary concern, is that all of my employees are able to go home and have dinner with their families every night." .... Construction Company Owner 
and traffic management/traffic control strategies. During the scanning portion of this review, the Review Team talked with owners, contractors, equipment manufactures, and road users organizations. Everyone is concerned about work zone safety and agree that completing the work safely is beneficial to everyone. The only questions are what is the most effective techniques and what devices are the most cost-effective? Several of the States included in the review have included work zone safety in their strategic plans and have established performance goals for work zone safety.

\section{OBSERVATION: Most States and local transportation agencies recognize the value of employing traffic management principles. However, their application has been limited to large high visibility projects.}

As noted earlier, work zone traffic management is not a separate program nor is work zone traffic management a new concept. Rather it is a series of comprehensive actions designed to minimize motorist delays while enhancing the safety of the motorist and the highway worker. The majority of previous State DOT efforts have been focused on safely handling traffic in project work zones and for the most part, these efforts are initiated near the end of the project design phase. However, more and more senior transportation officials are concluding that the key to minimizing motorist delays during construction and maintenance operations is to identify the impacts that the proposed work can have on traffic and/or adjacent residents and businesses in sufficient time to develop and implement the appropriate cost-effective mitigative measures prior to the delays occurring.

The Review Team was made aware of a number of isolated examples of excellent traffic management strategies that had been successfully implemented by the States on large high visibility projects. However, impact analyses are not routinely performed early in the project development stage, to identify

"The public is not satisfied with the status quo. They're tired of the way we've always done it." .... State DOT Official

\section{traffic impacts so that the appropriate}

traffic management can be applied on the majority of construction and maintenance projects. This observation is attributed to reduced staff, limited budgets, and the additional up-front time needed for cross cutting-teams to develop traffic management plans (TMPs) and to involve other stakeholders in the process.

\section{OBSERVATION: Although a few transportation agencies have begun to implement corridor management techniques, corridor traffic management is still in its infancy.}

The corridor approach to traffic management is a systematic process for upgrading, operating, and maintaining the highways in a traffic corridor. It combines engineering, economics, customer services, and business principles into a logical decisionmaking process to cost-effectively address both short- and long-term needs. 
"The corridor approach is a balancing act to get the work in sync... what work can we delay and what work can we afford to accelerate." .... Toll Authority Official

Corridor traffic management is beginning to take hold in several States on high volume traffic corridors with limited right-of-way. The move to the corridor approach is being driven by the fact that it is simply impossible to maintain a satisfactory level of service on a facility that is operating at or above capacity before the reconstruction/rehabilitation work begins.

Several of the City DOTs, Toll Authorities, and States with major metropolitan areas stated that an integral part of the corridor approach involves the scheduling, sequencing, packaging and coordination of all interagency, as well as intra-agency construction and maintenance

"One of the keys to reducing traffic volumes and disruptions in work zones, is the proper grouping and sequencing of projects."

... City DOT Official activities in the corridor.

Some of the State DOT officials advised that it is necessary to develop broad corridor traffic management strategies prior to submitting the State Transportation Improvement Plan in order to facilitate the budgeting and project approval processes.

\section{OBSERVATION: Some States utilize cross-cutting teams and proactively seek the input from external stakeholders in the development of the project traffic management plan.}

Previous State efforts have been primarily focused on safely handling traffic in project work zones. The majority of these efforts have been initiated near the end of the project design phase. As noted previously, the Review Team found some isolated examples of excellent traffic management strategies that have been implemented on large high visibility projects. However, impact analyses are not routinely performed early in the project development stage to provide for input from external stakeholders or for the appropriate traffic management strategies to be applied on the majority of projects.

The States that have successfully used project TMPs attribute their success to the fact that they had actively sought the involvement of the public, local governments, elected officials, road-user groups, and residential and business associations during the early phases of the design (+/- 30 percent design completion). These States also used multi-disciplinary teams (pavement, bridge, construction, design, maintenance, traffic operations, safety, finance, and environment) to ensure a cost-effective balanced design. 
"Our traditional way of doing projects was to take a lane and do the work at night. However, when we have gone to the public with options and given them a choice, they have chosen a closure option. ... They want us to get in, get out quickly, and stay out!"

.... State DOT Official

A number of States conduct constructability reviews on large, complex projects during the later phases of project design (+/- 80 percent complete). Traditionally these reviews are performed by inhouse personnel, the design consultant, and/or FHWA personnel. Several of the States include the contractor's associations in their reviews. Most of the reviews at this stage $(+/-80$ percent complete) are focused on detecting plan errors and clarification of the plans and specifications. Only a few of the review States include the contractor's associations and routinely conduct constructability reviews during the early phases of design (+/- 30 percent ). These States recognize that the contractor is the expert in determining the most economical and expedient manner of constructing the project. They utilize this expertise in phasing the construction and focused these reviews on maximizing the contractor's production and minimizing the interference with

"Getting the contractors involved in sequencing the job during the preliminary design phase makes a lot of sense." .... AGC Official

traffic. The contracting

organizations included in this review were very supportive of contractor involvement in the early phases as long as the integrity of the bidding system was not compromised.

One of the review States hired a retired contractor on a part-time basis to serve as a consultant to the design squads. They advised that this individual had proven to be very beneficial in sequencing, reviewing the plans from the contractor's view point, establishing contract time, and solving field problems during construction.

"It needs to be a team effort to build for success."

.... AGC Official

OBSERVATION: Traditional bidding procedures do not reward or encourage contractors to produce higher quality work and/or expedite the completion of the work.

Many of the States stated, they are very liberal in the amount of time allowed in their contracts. All of the contractors were in favor of contract incentives and a large majority were very supportive of time-based bidding. 
"We estimate contract time based upon the time it will take an average contractor to complete the work."

... State DOT Official

"Incentives are the key to getting projects completed faster"

... AGC Official

Most of the States have tried one or more of the time-based bidding techniques on selected high volume projects in urban areas. However, time-based bidding is not routinely used. The majority of States believe that $\mathrm{A}+\mathrm{B}$ bidding and Incentive/Disincentive (I/D) clauses have been very effective in reducing the time to complete the projects. Many States cited examples when one or two construction seasons had been eliminated by A+B bidding procedures. While lane rental is not as popular, several States advised that lane rental had been very effective in substantially reducing the number of lane closures. However, they cautioned that when lane rental is used without an I/D clause or $\mathrm{A}+\mathrm{B}$ bidding, the overall project completion date may be extended even though the number of lane closures is reduced.

A few of the States expressed a reluctance to pay a bonus for early completions. Their reluctance was over spending "hard dollars" (DOT budget) to minimize the "soft cost" (road-user cost).

Other DOT executives stated they had never been criticized for spending their funds to minimize the delays to the traveling public.

Several States are using "window specifications," i.e., a flexible Notice to Proceed Date along with a short performance period during which the lane restriction work must be completed within a longer overall project completion time period. Window specifications give the contractor adequate time to plan his/her operations, order materials, and provide maximum flexibility in scheduling equipment and personnel. This technique has also proven to be very effective in minimizing the interference with traffic.

"Give the contractors as much flexibility as you can and you'll get a better job that is completed quickly." .... AGC Official

\section{OBSERVATION: Traditional traffic control practices do not encourage the contractors to minimize motorist delay and/or enhance the safety of the work zone.}

The FHWA's present policy requires the owner to include a Traffic Control Plan (TCP) in the bid proposal and unit pay items for each of the traffic control items. While this policy, adopted in 1976, was a major factor in improving the safety and uniformity of work zones, it places the burden 
squarely on the contracting agency. The contractor has very little ownership of the TCP and has a financial incentive to use more traffic control devices. Several contractors stated they make money by placing barrels to close a lane even though no work is planned in that area in the foreseeable future. Additionally, the FHWA's policy of not allowing the contractor's name to be posted in the work zone relieves them of some of the responsibility/accountability for minimizing delays to the traveling public since most of the public's criticism is directed to the contracting agency. Traffic control is one of the only areas that the FHWA has not promoted the use of performance-based specifications.

\section{OBSERVATION: Prediction models are available; however, current usage is generally limited to large highly visible projects.}

States routinely use computer modeling to predict traffic conditions in work zones as part of the decisionmaking process on large highly visible projects. However, computer modeling is not routinely done in either the project planning or the design phase in most States.

Computer models are available to predict queue lengths, delay times, and travel speeds. However the available models/analysis tools are not user friendly and are not readily adapted to local traffic situations experienced during construction. Additionally, the prediction models are primarily geared to linear freeway operations. Several States advised the Review Team that they found it necessary to adjust the model results to fit actual traffic responses in their State and/or locations within their State. Some of the States that utilize work zone traffic modeling have accepted the number of minutes of delay predicted, but raised questions about the validity of the dollar value assigned to delay time. They believe that different dollar amounts should be used for different types of motorists, such as vacationers, salesmen, and retired persons.

\section{OBSERVATION: There is a compelling need for a comprehensive effort to educate the general public, road users, and elected officials on: the need for work zones; how to navigate safely through a work zone; and the dangers associated with them.}

Virtually every transportation official participating in the review stated that the industry has not done a very good job of educating the drivers and the public about work zone issues.

Several States have produced video tapes on work zone safety. Some of these videos were produced for the general television audience; others have
“We don't do a good job in public relations--Our public affairs are reactive and we need to be proactive."

.... State DOT Official 
been produced, in cooperation with trucking associations--targeted for commercial drivers. Three of the States included in the review have produced videos and other work zone educational materials for elementary, middle, and high school students. In addition, these DOTs have prepared work zone information for driver education instructors. Employees in these States have also been active in making work zone safety presentations at the schools. One of the review States has a contractual relationship with the American Automobile Association Chapter to make work zone safety presentations in the schools.

A few of the review States have recently updated the work zone information in their drivers manuals. Two of the States have been successful in having a work zone question included on all driver's license tests.

These educational efforts noted above are designed to inform the driver of the inherent danger of work zones, what work zone signs and pavement markings mean, and how to safely navigate through a work zone.

Another aspect of the educational effort is to educate the public and elected officials about the need for preventative maintenance and why the work has to be done at certain times. However, the Review Team was not made aware of much activity in this area.

The third aspect of education is work zone safety training for highway workers. All of the States have work zone safety training for their employees. Many States also offer work zone safety training to contractors and design consultants. A number of the review States require the contractor to have a Certified Traffic Control Person on the project. However, only a few of the States have offered work zone safety training for utility companies.

"The public doesn't know whose cones are blocking a lane. We get the blame even if it is a utility or a local government."

.... State DOT Official

\section{OBSERVATION: All transportation agencies are experiencing the customers' increasing demand for accurate real time information. Most State DOTs are meeting their customers' needs on high impact projects; however, a few agencies have expanded their program to include all projects.}

Virtually all transportation agencies recognize the importance of a proactive approach in providing the public with advanced information on construction projects, detours, and major lane closures. Most all of the highway agencies publish an annual list of construction projects and make this information available in welcome stations, rest areas, and truck stops.
"Effective communication is a key to reducing congestion and minimizing delays."

.... State DOT Official 
Many State DOTs use highway advisory radio. All of the highway agencies are routinely using variable message signs to inform the motorist of detours, lane closures, and backups.

Highway agencies have also been proactive in providing project status updates and real-time traffic information on high impact projects. This is done through radio, television, newspapers, faxes, 800 telephone numbers, and the Internet. However, this same type of information is usually not available on routine projects in urban areas or on rural Interstate projects.

Many of the States included in this review have established a public relations position(s) or hired a consultant who is dedicated to providing the public with up-to-date information on construction projects and advanced information on detours and lane closures. In addition, real time traffic information is provided to the public and media in the major urban areas.

"If the motorist is given enough information ahead of time, some of the traffic will disappear." .... State DOT Official

\section{OBSERVATION: There is universal agreement that the most effective way of controlling speed in the work zone is to have a staffed police car with flashing lights at the beginning of the work zone.}

Most States are doing more and more night work to avoid the heavier traffic volumes. However, higher speeds, reduced visibility, impaired drivers, driver fatigue, and driver inattention are more prevalent at night. All of which increase the need for more police in the work zone.

"No technique is as effective in getting the driver's attention to slow down than a staffed police car with flashing lights at the beginning of the work zone."

.... State DOT Official

The limited amount of work zone crash analysis that has been done shows the two leading causes of work zone crashes are excessive speed and driver inattention. All of the participating transportation agencies and contractors agree that a staffed police car with flashing lights at the beginning of the work zone is the most effective way to reduce speed in the work zone and get the driver's attention. Some of the highway agencies expressed concern about the limited number of police in some locations, as well as the cost involved in using police in work zones.

One of the review States has a dedicated number of full-time State Police assigned to the State DOT district offices for work zone duties. While their primary duties are speed enforcement, work zone safety, and crash investigation/reporting in the work zone, the police also assist with traffic control setups, compliance with the TCP, and Occupational Safety and Health Administration compliance.

Many States have enacted legislation to double fines for speeding in work zones. While this is a deterrent, for the law to be effective and enforceable, an additional responsibility rests on the State 
DOTs and contractors to ensure that the signs are only posted when the work zone is active and are covered when there is no activity in the work zone.

Motorist credibility is also a major issue in controlling speed in the work zone. The presence of barrels and reduced speed limits coupled with no visible work taking place within a work zone has the public questioning the highway community's credibility. During the scanning portion of this review the Review Team observed work zones that had lower speed limit signs posted with no work taking place and no geometric restrictions. A few of the States advised that, due to liability issues, their specifications require the work zone signs to remain in place until the project is accepted by the State. Most contractors and owners expressed the belief that drivers do not slow down unless they see workers close to the driving lanes or they perceive a need to slow down.

\section{OBSERVATION: ITS technology has not been adapted/applied into work zone traffic management.}

While fixed traffic management systems are in place in a number of large metropolitan areas and have been used to monitor traffic flows during construction, many times communications links are cut and operations disrupted during the first phase of reconstruction projects.

During the scanning portion, the Review Team discussed a number of ITS applications for work zones. All of the participants agreed that there are a number of ITS applications that could be effectively used to inform the public of work zone delays, warn the motorist approaching backups, control speed, facilitate the flow of traffic, and minimize delays in work zones. The ITS can also be used to collect and analyze before, during, and after traffic flows, as well as, to measure the effectiveness of work zone traffic management strategies, traffic control techniques, and traffic control devices. Additionally, ITS can also be used to collect and analyze the data needed to establish performance goals and measure results.

The use of portable traffic management systems looks extremely promising. While there are two prominent portable systems that are currently available, only a few States have tried or evaluated either of these systems.

The technology is available; it is a matter of "tweaking" the software of the portable traffic management systems and placing a priority on adapting other ITS applications to work zones.

\section{OBSERVATION: There is a compelling need for accurate work zone crash data and the evaluation of traffic handling techniques in order to make sound decisions.}

A few studies have been conducted on work zones crashes and work zone issues. However, very little research has been done on the root causes of work zone crashes; the effectiveness of traffic control devices; and/or traffic handling techniques. This situation is due, in part, to the lack of a accurate work zone crash data and a uniform definition for work zones. 
Accurate work zone crash data is needed to properly analyze the root causes of crashes. A number of States reported that the crash data recorded on their accident report form varies from one location to another and one officer to another. During the review, the Review Team found several instances where the number of work zone fatalities in FARS was substantially lower than the numbers of fatalities being used by the State DOT. Without complete and accurate crash data, trends cannot be established and officials cannot make rational cost-effective corrective action decisions, but rather have to rely on their engineering judgement.

The Review Team also found that there is a need for a uniform definition of a work zone. Discussions with the various State highway agencies revealed the lack of a uniform definition is resulting in a disparity in recording of work zone crash data. Without a uniform work zone definition and uniform crash data on the accident report form, the data recorded can not be properly evaluated to determine the cause and effect of the crash. 


\section{State of the Art - Reducing Delays and Enhancing Safety in Work Zones}

During the scanning portion of this review, the Review Team asked our partners, stakeholders, and senior managers to share their vision concerning the way construction and maintenance operations should be conducted in the future. Specifically, the Review Team wanted to define how projects needed to be planned, programmed, and designed; what refinements in scheduling and contracting procedures should be considered; identify recommendations for improved construction methods, materials, and equipment; and to define the organizational structure and funding mechanisms needed to support their vision.

Senior managers agreed that today's routine practices cannot be continued. Changes must be made if we are going to meet our customers' increasing need for mobility and safety in work zones and if we are to overcome the backlog of highway needs. There was also total agreement among the participants that, in addition to the engineering aspects, owners and industry must become actively involved in work zone public education, public information, traffic management, and enforcement if we are to substantially reduce delays and enhance work zone safety. Additionally, a major shift in emphasis from handling traffic on individual projects to corridor traffic management, a customer focus, contractor input, and public participation in the early traffic management decisionmaking were noted as key ingredients to a successful program of enhancing future operations to minimize delay, reduce congestion, and enhance safety for both the motorists and the roadway worker.

"To achieve the state of the art in work zones we have to change organizational mind sets from one of planning, designing, constructing, operating, and maintaining highways to the safe and efficient movement of goods and people." FHWA Official

However, most of these individuals did not envision quantum changes to construction methods, materials, and/or equipment in the near future, but shared the view that the state of the art would be achieved through continuous improvements to today's state of the practice. The Review Team consolidated the information learned during these discussions into a state-of-the-art statement for each of the elements of work zone traffic management. 


\section{$\&$ Policy and Procedure}

\section{STATE-OF-THE-ART}

Decisions are based upon a customer driven comprehensive work zone traffic management policy that focuses on reducing the exposure of the road user and worker. This policy addresses high-quality design, construction, and maintenance operations, minimizing disruption to the highway user and maintaining a safe, efficient roadway environment for the traveling public and the highway worker. The organizational structure fully supports cross-cutting teams in all phases of work zone traffic management where capacity reductions adversely impact traffic flow.

To achieve state-of-the-art policy and procedures, transportation agencies would need to:

! Adopt strategic goals, objectives, and performance measures that define the Agency's expectations for allowable travel delay and crash rates.

! Provide an organizational structure that provides cross-cutting teams that tap the expertise and proactive involvement of the all disciplines in the development and selection of corridor TMPs and project TCPs.

! Re-evaluate policies and procedures to ensure:

C Contractor's participation in the development of the TCP, responsibility for successful implementation of the TCP, and rewards for exceeding expectations, i.e., a move towards performance-based traffic control specifications.

C Utilization of road-user costs, economic impacts to the business community, and lifecycle-cost in the decisionmaking process.

C Public participation during the development and selection of corridor TMPs and project TCPs.

C Customer feedback and evaluation.

C Traffic management principles that focus on reducing the exposure of road-users and workers are integrated into all related manuals and guidelines, such as project development schedules, design manuals, consultant selection, and the Manual on Uniform Traffic Control Devices (MUTCD).

Develop and deliver training courses in work zone traffic management principles and strategies. 


\section{\& Public Relations, Education, and Outreach (General Public, Driver, and Elected Officials)}

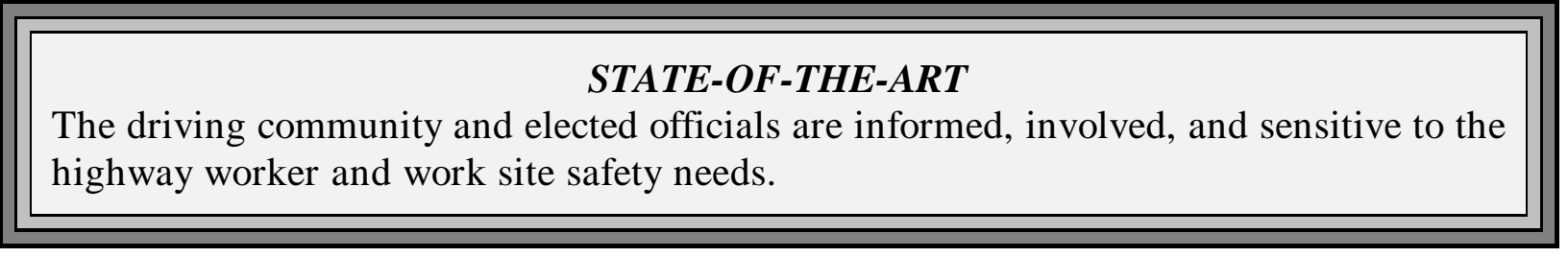

To achieve state-of-the-art education and outreach, transportation agencies would need to:

! Assume a proactive leadership role in work zone educational efforts.

! Develop, update, and distribute work zone safety educational materials for:

C Driver handbooks/manuals

C Commercial drivers handbooks/manuals

C Driver license test questions

C Driver education courses

C Teaching modules for elementary and secondary schools

C Media (television, radio, newspaper)

C Road user groups, insurance companies, rental car agencies (magazines, newsletters, inserts)

C Elected officials

! Develop media partnerships to educate and inform the public about work zone safety.

! Sponsor national and State work zone safety awareness initiatives.

! Share work zone public service announcements and educational materials with other highway agencies.

! Develop guidance and tools to assist decision makers in balancing the expenditure of additional funds for longer-lasting materials and designs in today's projects to achieve a faster delivery, a longer service life, and reduce future motorist delay and exposure.

! Update the National Highway Institute (NHI) work zone training courses and expand the audience to include designers, State police, local public agencies, utility companies, consultants, and contractors. 


\section{\& Prediction Modeling and Impact Analysis: Congestion and Crashes}

\section{STATE-OF-THE-ART}

Available prediction/analysis tools are user-friendly and readily adapted to the local construction site and situation. These tools can accurately analyze and reliably predict congestion situations including travel times, queue length, travel speed, total delay, crash rates, severity levels, and interactive feedback to both the design and construction team.

To achieve state-of-the-art prediction modeling and impact analysis, transportation agencies would need to:

! Update and enhance existing computer modeling software to make it user-friendly and to realistically predict traffic impacts (travel times/speed, queue lengths) and the crash potential (frequencies and severity) for various reconstruction alternatives on freeways as well as urban arterial grids.

! Develop user-friendly computer modeling software (PC based) for analyzing proposed project specific changes to the traffic control plan at the project site. (Comparisons of travel times/speed, queue lengths, as well as crash frequencies and severity.)

! Develop user-friendly project specific computer software (PC based) that can predict capacity breakdown on freeways before it occurs.

\section{\& Planning and Programming}

\section{STATE-OF-THE-ART}

A corridor approach is used in evaluating, planning, and programming. This process gives full consideration to long-range corridor needs, traffic demands, road-user costs, potential business community impacts, use of extended designs and high-performance materials, and overall evaluation of total costs for the life of the improvement.

To achieve state-of-the-art planning and programming, transportation agencies would need to:

! Optimize the grouping and sequencing of long-range corridor improvements (capacity, structural, operational, and system preservation) into projects which minimize traffic delays, reduce the exposure to motorist and workers, as well as provide for the safe, efficient travel needs of today and for future generations. 
! Routinely program systems preservation, including dedicated funds to provide for planned preventive maintenance treatments performed at the right time.

! Integrate work zone traffic management principles into the FHWA planning and National Environmental Policy Act (NEPA) processes.

! Utilize cross-cutting and multi-agency teams to develop corridor traffic management plans.

! Give full consideration to road-user costs and impacts to affected business and residential communities in the selection of the corridor TMP.

! Conduct public relations campaigns that inform the public and involve them in the selection of corridor TMPs.

\section{\& Project Development/Design}

\section{STATE-OF-THE-ART}

Motorist delay, road user, worker safety, and impacts to adjacent communities are assessed on all major urban and other high volume corridors. Cross-cutting teams and multi-agency/interests are used in developing alternatives and selecting the preferred design that minimizes present and future exposure to road users and workers. The project development process results in a TCP that provides for shared risk and benefits for owners, contractors, and the traveling public. Contract times and motorist delays are minimized through the use of CPM scheduling and accelerated contracting procedures.

To achieve state-of-the-art project development/design, transportation agencies would need to:

! Extend traffic management principles into all construction and maintenance projects adversely impacting traffic, not just high visibility projects.

! Develop TCP options prior to beginning the detailed design (+/- 30 percent stage).

! Utilize cross-cutting teams to develop and evaluate TCPs.

! Provide for contractor involvement in the development of the TCP and active public input into the selection of the TCP.

! Use computer modeling to assess the traffic and safety impacts as well as the construction time required for the TCP options being considered. 
! Modify project development schedules to reflect development and evaluation of TCP options prior to beginning detailed designs (30 percent stage).

! Consider road-user, life-cycle, and other impact costs in the selection of the preferred design, materials, TCP, and contracting options.

! Utilize CPM scheduling to establish the maximum contract time included in the bid proposal.

! Develop user-friendly computer software to calculate realistic, but expedited contract times.

! $\quad$ Provide CPM scheduling training courses to staff and consultant designers.

! Conduct public relations campaigns to inform the public and involve them in the selection of the preferred TCP.

\section{$\&$ Contracting and Bidding Procedures}

\section{STATE-OF-THE-ART}

Contracting and bidding procedures reward contractors for quality work, innovation, accelerated early completions, minimizing motorists delays, and enhancing the safety of road-users and workers. On high-risk, high-visibility, and complex projects contractors are pre-qualified on the basis of quality and past performance.

To achieve state-of-the-art contracting and bidding, transportation agencies would need to:

! Utilize time-based bidding and flexible Notice to Proceed dates on all projects which adversely affect the existing level of service.

! Incorporate the quality and timeliness of a contractor's past performance into prequalification procedures.

! Update and enhance existing computer software for calculating road-user costs to make it user-friendly and ensure that outputs are realistic and legally defensible. 


\section{\& Specifications and Construction Materials, Methods, and Practices}

\section{STATE-OF-THE-ART}

The same level of service is provided through the work zone. Workers are physically separated and are protected from the traffic. Work areas are sufficiently illuminated at night without blinding the motorist and gawk screens are used to prevent the motorists from being distracted during daytime operations. Contractors have a vested interest in quality, timeliness, and road-user safety. Facilities perform at an acceptable level of service for 35-50 years with the minimum planned system preservation. Acceptance is based on performance.

To achieve state-of-the-art construction materials, methods, and practices transportation agencies would need to:

! Revise prescriptive-type specifications to performance-based specifications.

! Adopt specifications that reward contractors for innovation, quality, and exceeding expectations.

! Develop and utilize performance-based specifications for traffic control.

! Routinely include warranty specifications with bonuses for exceeding the expected life of the end product.

! Require positive barriers to physically separate the workers from the traffic.

! Adopt specifications that require adequate lighting for all nighttime operations, lane shifts, lane drops, and temporary gores.

! Insist on quality work and timely completion of the work.

! Develop short-term testing and modeling for newly constructed highway components to reasonably predict long-term performance and remaining life.

! Develop design specifications, guidelines, and testing methods for composite materials.

! Standardize design details to encourage a greater use of precast materials.

! Provide real time work zone traffic information to road users and workers in sufficient time to make informed decisions. 


\section{$\boldsymbol{\&}$ Traveler and Traffic Information (Project Related)}

\section{STATE-OF-THE-ART}

Accurate real-time work zone (construction/maintenance/utility operations) information is provided to the road users in sufficient time to make informed travel decisions.

To achieve state-of-the-art traveler and traffic information at the project level, transportation agencies would need to:

! Monitor work zone traffic conditions on all NHS projects on a Statewide/area-wide basis through fixed traffic management systems, portable traffic management systems, and/or cameras tied into a Statewide/area-wide communications system.

! Display real-time work zone traffic conditions on the Internet, large screens at rest areas, welcome centers, weigh stations, truck stops, major tourist attractions, large parking garages, large office buildings, employment centers, and/or other large traffic generators.

! Use changeable message signs, traffic advisory radio, and early warning systems to warn motorist approaching congested work zones.

! Use ITS hardware to safely guide motorists through the work zone.

! Develop media and private sector partnerships that provide real-time work zone information to the public.

\section{\& Enforcement}

\section{STATE-OF-THE-ART}

Work zone trained and qualified, full-time uniformed police officers are readily available for construction and maintenance operations. State-of-the-art technology is used to maximize effectiveness of these police officers.

To achieve state-of-the-art enforcement, transportation agencies would need to:

! Utilize uniformed police officers in all work zones on high speed, high volume facilities, as well as, those involving lane and ramp closures, severely restricted areas, and where major changes to existing traffic patterns result. 
! Provide training for uniformed police officers in work zone traffic control, completing work zone data on State accident/crash report forms, the MUTCD, and incident management.

! Secure dedicated, full-time uniformed police officers for work zone enforcement activities.

! Use automated speed enforcement in confined and high-speed work zones.

! Equip uniformed police officers with state-of-the-art equipment for use in controlling speed, and crash investigation/reporting.

\section{\& ITS and Innovative Technology}

\section{STATE-OF-THE-ART}

The ITS systems are used to automatically collect and analyze before, during, and after traffic flows in the work zone; provide accurate real-time information automatically to motorists and to the construction team; enforce speed; as well as safely guide motorists through the work zone.

To achieve state-of-the-art ITS and innovative technology, transportation agencies would need to:

! Enhance the software and communication modules in existing portable traffic management systems, in order to provide accurate real-time traffic information automatically to motorists and the construction team.

! Utilize portable or fixed traffic management systems to collect and disseminate real-time information to motorists in all work zones:

C On high-speed, high-volume facilities,

C Involving lane and ramp closures,

C Located in severely restricted areas, and

C Involving major changes to existing traffic patterns.

! Develop effective tools and techniques for safely and efficiently merging traffic approaching a work zone with lane closures.

! Develop effective tools, techniques, and enforcement for slowing down traffic approaching work zones, as well as maintaining a safe speed through work zones.

! Develop automated/robotic equipment to perform high-exposure, short-term maintenance operations. 
! Develop a positive barrier system, with a gawk screen, that provides lateral protection to workers performing mobile construction and maintenance operations.

! Develop a cost-effective, positive barrier system that provides lateral protection to workers performing static short-term maintenance operations.

! Develop erasable, temporary pavement markings that do not produce a shadow/ghost when removed.

! Develop a cost-effective, quick way to remove, cover, and/or obliterate existing pavement markings to prevent a conflict with new markings; and/or do not produce a shadow or ghost.

! Showcase success stories.

\section{$\boldsymbol{\&}$ Evaluation and Feedback}

\section{STATE-OF-THE-ART}

Uniform work zone crash data is collected electronically in all States and the raw data is simultaneously transmitted to the State DOT. Work zone crash data is automatically analyzed and trends and reports are periodically furnished to appropriate DOT offices (including, but not limited to, design and construction project personnel). Performance measures for work zone congestion/delay are used to evaluate how well agencies are meeting performance goals for mobility and safety in work zones. Motorists provide perspectives on how well their demands for mobility and safety in work zones are being met.

To achieve state-of-the-art evaluation and feedback, transportation agencies would need to:

! Adopt uniform work zone definitions and work zone data for reporting work zone crashes.

! Develop performance measures for work zone congestion and delay that can be applied to a specific project, as well as, Statewide and nationally.

! Develop and implement an electronic crash data collection system that simultaneously transmits the raw work zone crash data to the DOT.

! Collect and evaluate before, during, and after work zone traffic flow data.

! Conduct project area-wide customer surveys to routinely evaluate work zone acceptability. 


\section{The FHWA's Leadership Role in Reducing Delays and Enhancing Safety in Work Zones}

Meeting the customers' needs for mobility and safety during construction and maintenance operations is the essence of what the highway industry does--planning, designing, operating, maintaining, rehabilitating, reconstructing, and making improvements to roads and highways are what it's all about. Almost everything the FHWA does is manifested in a work zone. What a motorist experiences in a work zone gets down to the very essence of what the FHWA is and does.

“Meeting our customers' demands for mobility and safety

in work zones gets at the heart of what we do!"

FHWA Official

The FHWA is regarded as a leader in highway issues affecting the nation. As such, States and local agencies look to the FHWA to take a leadership role in reducing delay and enhancing safety in work zones--to set a course and challenge them to take a leadership role in this area.

During the scanning portion of this review, field offices, State DOTs, counties, cities, contractors, user groups, and equipment manufacturers identified six major roles in which the FHWA should take a leadership role and which they look to the FHWA to perform:

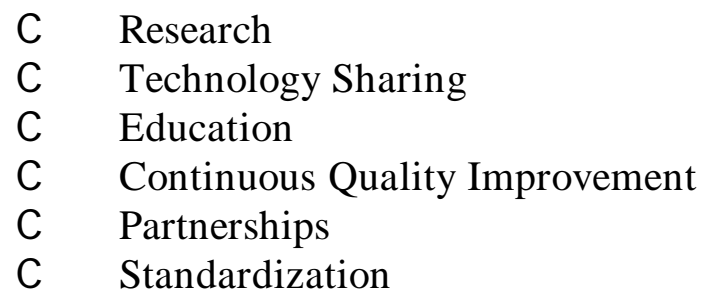

\section{Research}

\section{EXPECTATION: The highway industry expects the FHWA to lead and coordinate the research and development efforts that address national needs.}

As a national organization with offices throughout the country, the FHWA has the unique ability (or opportunity) to be aware of research and development needs and what efforts are needed to address those needs. Again, rather than each agency, organization, or industry conducting their own research and development efforts, they look to the FHWA to lead and coordinate efforts in research topics of interest for most States. On these broad research topics, they also expect the FHWA to conduct detailed research to address common problems. This includes efforts of developing and/or enhancing software and developing and testing work zone devices and materials that meet State DOTs' near-term needs and strategic goals and objectives. For example, the National Cooperative Highway Research Program (NCHRP) is viewed as a vital program as it meets the needs of many agencies and leverages more funds to conduct needed research. 
As previously mentioned, State DOTs don't want the FHWA to just send them the information, but also to help demonstrate and implement the research. They want ideas, devices, and technologies to be ready for deployment before they are put into effect. For example, during the review several topics were repeatedly identified which States felt the FHWA should pick up for further development. These included: getting motorists to merge prior to the lane drop preceding the work zone; complete development and implementation of portable traffic management systems; and refinements to software for determining road-user costs and modeling traffic impacts.

\section{RECOMMENDATIONS:}

\section{Headquarters Product Teams:}

h Partner with equipment manufactures to enhance the capabilities of Portable Traffic Management Systems and proactively demonstrate the benefits of Portable Traffic Management Systems.

h Develop and/or enhance user friendly software to model work zone delay, queues and crashes; calculate defendable road-user cost and proposed contract time; evaluate proposed changes to the TCP as well as analyze work zone crashes. All software must be sufficiently flexible to allow for variable parameters to meet unique State/local conditions.

\section{Technology Sharing}

\section{EXPECTATION: Our customers expect the FHWA to share the best practices/techniques/technology of others to assist them in implementing the ones that meet their needs.}

Virtually every agency/organization expressed the desire for the FHWA to play a major role in technology sharing. As a national agency with offices throughout the country, State DOTs look to the FHWA to be aware of and to share what others are doing. They expect the FHWA to keep them advised of successes and failures from around the country.

"Let us know what works around the country. Get the information out to our people. If they pick up one good idea, we'll save the traveling public millions of dollars and significant time." State DOT Official

However, the participants noted the amount of information and the number of periodicals and reports is overwhelming. The States remarked they do not have the time to keep up with all the

“Just sending over a report doesn't meet our needs. We look to the FHWA to assist us in implementing the new idea."

...State DOT Official information or read all of the details in all of the reports. What they want and need is for the FHWA to assist them in identifying 
new ideas, best practices, and technologies that will help them solve their problems and improve their operations. Once these new ideas, best practices, and technologies have been identified, they look to the FHWA to assist in implementation. The National Work Zone Safety Information Clearinghouse generated a great deal of interest during the scanning visits and was cited as a new idea/best practice that fills a void.

A number of the review States stressed that the FHWA needs to recognize that "one size does not fit all." Just because new ideas, practices, or technologies have been successful in one State does not mean that it will work everywhere. State DOTs want the FHWA to be familiar with their operations and problems so the FHWA will be in a position to help identify and implement solutions.

Many of the State DOTs included in the scanning portion of this review felt that the FHWA should be more willing to take a risk and try new ways/things. They want the FHWA to partner with them in trying some of their new ideas, then "if it doesn't work, drop it." Flexibility was noted as a key to developing better ways of doing business. For technology transfer to be successful, the FHWA's efforts must be adapted to an individual agency's needs.

"Many times we feel like the FHWA has a solution looking for a problem to solve." .... State DOT Official

State DOTs were very supportive of the FHWA's past

efforts of sponsoring regional workshops, peer reviews, and scanning trips. Many States are very strict on out-of-state travel, therefore, the FHWA's assistance was stated as a necessity for technology sharing to be successful.

\section{RECOMMENDATIONS:}

\section{Headquarters Product Team:}

h Develop an ITS and implement an action plan of the activities required to achieve the state of the art by integrating ITS concepts and technology into construction and maintenance operations. These activities include, but are not limited to, the production of guidance materials, workshops, training courses, seminars, technical assistance programs, etc.

\section{Resource Center Product Teams:}

h Identify and disseminate work zone information through showcases, peer exchanges, and maintaining an up-to-date list of work zone best policies/practices on the FHWA Home Page. Facilitate the sharing of work zone information by delivering work zone training to meet State/local needs, conducting work zone workshops and assisting in the implementation of new technology. 


\section{Division Office Product Teams:}

h Identify and proactively share best practices/policies that may solve the State's problems as well as assist in the implementation of new technologies/best practices to reduce the road user's and the road worker's exposure in work zones. Conduct annual listening sessions, with State DOTs, to solicit work zone technology needs.

\section{Education}

\section{EXPECTATION: The highway community looks to the FHWA to develop educational materials and to partner with them in their delivery, as well as in outreach efforts to educate the public, road-users, and elected officials.}

Again, virtually every agency and organization participating in the scanning portion of this review commented on the overriding need for the highway community to do a better job of educating the public. That includes education of road users, elected

"We have to let people know what we're doing and why we're doing it." State DOT Official officials, legislatures, those in drivers training, and school children. Rather than have each agency, organization, or group develop their own program; the transportation community looks to the FHWA to develop model programs and generic materials which could be used, expanded upon, and given a local flavor by the individual groups. The "Get the Picture, Listen to the Signs" work zone safety outreach campaign partnership with 21 States to improve safety of work zones is an excellent example of a cooperative educational effort.

Some of the participants noted that a great impact can be made by educating school children. Not only do the children gain an understanding of the importance of why there are work zones, but also the reason they are necessary, and why it's important to be more alert and slow down in work zones. In addition, school children have a strong influence on their parents and grandparents and can often get through to these groups more readily than through adult educational efforts. Drivers-in-training need to know what a work zone is, what the signs mean, what actions are required, and why it's important to safely navigate through work zones. Drivers in general need to know why work zones are necessary, what the work zone signs mean, and how to safely navigate through work zones. State, local, and

"The three keys for success are engineering, education, and enforcement. Today we're working in engineering and enforcement. What we need for tomorrow is to stress education and public relations." State DOT Official national politicians need to understand the importance of funding system preservation types of improvements to the highway infrastructure and how critical it is to do the right preventive maintenance treatment at the right time. However, to gain the maximum support, the highway community has to demonstrate a more customer-focused approach to providing transportation. This includes reducing delays, accelerating construction, informing the road user of work zones in advance, and providing more accurate, credible, and real-time information. 


\section{RECOMMENDATIONS}

\section{Headquarters Product Teams:}

h Facilitate an organizational understanding of work zone traffic management versus traffic control. This includes integrating traffic management principles into the early phases of the FHWA's Project Planning and NEPA Processes, developing a NHI course on work zone traffic management, and updating the NHI work zone training courses by incorporating work zone traffic management principles.

h Develop work zone education and awareness materials which can be tailored to individual State and local use. These include, but are not limited to: preparation of work zone articles which can be used by the media, schools, national road-user organizations, advocacy groups, and insurance companies. Promotion of an annual national work zone fatality free day, in cooperation with the highway community, to highlight work zones.

\section{Resource Center Product Teams:}

h Identify and disseminate work zone information through showcases, peer exchanges, and maintaining an up-to-date list of work zone best policies/practices on the FHWA Home Page. Facilitate the sharing of work zone information by delivering work zone training to meet State/local needs, conducting work zone workshops and assisting in the implementation of new technology.

\section{Division Office Product Teams:}

h Promote, encourage, support, and partner with the State DOT in work zone educational outreach efforts.

\section{Continuous Quality Improvement}

\section{EXPECTATION: The State DOTs look to the FHWA to be proactive in challenging, motivating, and facilitating their continuous quality improvement efforts.}

State DOTs are expected to deliver the program. As a result of downsizing and day-to-day pressures, many do not have the time and/or resources to challenge their own efforts. They look to the FHWA to challenge, motivate, and facilitate their quality improvement programs through proactive efforts by the divisions. They also look to

"We don't have time to be creative." ..State DOT Official the FHWA to continuously challenge their thinking about the effectiveness of their programs, to assist them in implementing changes, and to improve the efficiency of their operations. The Model Traffic 
Management Program for Minimizing Motorist Delay and Enhancing Safety During Construction and Maintenance Operations and the Self Evaluation Guide for benchmarking provide an excellent opportunity for the FHWA and State DOT jointly undertake quality improvement efforts.

The DOTs look to the FHWA to identify problems before they occur and assist them in implementing solutions that prevent potential problems. In addition, they look to the FHWA to support customer-driven construction initiatives and to be willing to take a risk by trying innovative ideas even if they are "out of the box." However, the State DOTs do not need or want the FHWA to "second guess" their decisions.

There is a definite correlation between the State DOTs' efforts and initiatives in minimizing delay and enhancing safety of the public in work zones and the proactivity of the division offices as noted in the FHWA Division Office Organizational Baseline Data. For example:

- of the 26 State DOTs with TMPs--23 divisions indicated they were proactive;

- of the 49 State DOTs that utilize police in work zones--38 divisions indicated they were proactive, and

- of the 45 State DOTs that have used innovative contracting--42 divisions indicated they were proactive.

Conversely, the FHWA Division Office Baseline Data Forms indicate that where the divisions have not been proactive, a significantly lower number of State DOTs have undertaken efforts or initiatives to minimize delay and enhance work zone safety. For example:
“We need something to get us off the bubble so we don't go back to our desks tomorrow and get immersed in other things that we have to do." .... State DOT Official

- only five divisions indicated they were proactive in promoting work zone performance measures--only 16 State DOTs have any type of work zone performance measures;

- only two divisions indicated they were proactive in involving motor carriers in evaluating and selecting TMPs--only four State DOTs solicit the expertise of motor carriers in evaluating and selecting TMPs, and

- only eight divisions indicated they were proactive in promoting the benefits using prequalification to restrict poor preforming contractors from bidding on critical time contracts -only 15 State DOTs have attempted to use pre-qualification in this manner.

As noted previously, work zone traffic management starts in the planning phase and continues through operations and maintenance. Therefore, it is most successful when undertaken by cross-cutting teams. 


\section{RECOMMENDATIONS:}

\section{Headquarters Product Teams:}

h Include work zone initiatives in the Annual Performance Plan. Establish work zone performance goals such as:

- A two percent reduction per year in fatalities in work zones, and

- A two percent reduction per year in construction time, motorist delay, and/or lane closure times.

\section{Resource Center Product Teams:}

h Develop and implement long term initiatives that will achieve the state of the art.

\section{Division Office Product Teams:}

h Proactively promote and challenge the State DOT to adopt work zone performance goals for motorist delay and work zone safety.

h Identify one or more work zone initiatives in the division's Annual Work Plan, to partner with State DOT's in reducing motorist delay and enhancing work zone safety.

h Benchmark work zone practices/policies jointly with the State DOT.

\section{Partnerships}

\section{EXPECTATION: The highway community looks to the FHWA to develop partnerships at the national level and to be a catalyst for establishing partnerships at State and local levels.}

If significant progress is to be made in reducing work zone delays and crashes, active partnerships must be developed with all of the stakeholders. The DOTs realize that they can not do it without the total support of the entire highway community. Again as a national organization, State and local agency DOTs, toll authorities, contracting "More now than ever partnerships will be paramount!" .... State DOT Official associations, and industry see the FHWA's role as working with and establishing partnerships with agencies and groups at the national level. These national partnerships are needed to provide the emphasis and framework; remove or reduce local barriers; and facilitate the development of similar partnerships at the State and local levels. Partnership efforts in education and outreach are needed to acquaint the public with the hazards of work zones and what they can do to improve safety. Scan participants noted that, through coordinated focused efforts, all partners can be more effective and improvement can be made in reducing exposure in work zones and in improving safety. 


\section{RECOMMENDATIONS:}

\section{Headquarters Product Teams:}

h Develop active partnerships with national level organizations and the media (television, newspapers, magazines, etc.) to provide focus; and consolidate efforts in work zone awareness, marketing, education, and training. Disseminate work zone educational materials.

\section{Division Office Product Teams:}

h Take a proactive leadership role, in cooperation with the States, to foster partnerships at the State and local levels which focus on reducing the exposure of road users and road workers.

\section{Standardization}

\section{EXPECTATION: The highway industry expects the FHWA to take a proactive leadership role and partner with national organizations in the development of uniform guidance and criteria that will ensure driver expectancy and protection of the workers and motorists, without stymieing innovation, ingenuity, and adaptation to local situations.}

One of the key roles the FHWA serves, is providing uniformity and standardization in work zones throughout the country so that driver expectancy is not compromised. Driver expectancy is one of the most basic tenets in safe highway

"We'd like the FHWA to assist and facilitate the standardization of specifications, standards, etc." State DOT Official design and efficient operations. Driver expectancy is the primary reason for standardization. However, our partners were quick to point out there needs to be some flexibility so as to not stymie innovation and ingenuity. State DOTs

suggested that the FHWA needed to take a broader view in work zone applications that meets the intent of the law.

There was also a great deal of concern expressed over NCHRP 350 and the lack of flexibility in adapting devices and techniques to local conditions. Several State DOTs were concerned that the "all or nothing" approach to devices was stifling, i.e., "When is being too safe going overboard?"

Concerns were also expressed about the strict adherence/interpretation of meeting Part VI of the MUTCD. It was felt that the intent "to protect and provide safety to workers and the traveling public" has been lost to a certain extent by the emphasis on strict compliance with the MUTCD.

Numerous State DOTs mentioned the need for standardizing methods for measuring and evaluating exposure and crash rates in work zones. Most States include work zone crash data blocks on their crash report forms. However, there is not a uniform definition of a "work zone" nor is there consistency in the additional work zone crash data collected. Once collected, very few States evaluate the causes of work 
zone crashes or can project expected work zone crash rates. The Review Team found data in the FARS that was, in many cases, the "tip of the iceberg." Numerous States noted the number of work zone fatalities was greater than reported in FARS. Again, consistency of crash data entry was cited as an area where standardization is needed, and that the FHWA should play a leadership role.

\section{RECOMMENDATIONS:}

\section{Headquarters Product Team:}

h Develop, in cooperation with our partners, a national definition for work zones and standardize the work zone crash data that is collected and reported.

\section{Division Office/Resource Center Product Teams:}

h Improve the uniformity and consistency in work zone crash reporting. This includes but is not limited to partnering with the State DOTs in providing training for State Police.

\section{Specific ways for the FHWA to exercise a leadership role in implementing the concepts and recommendations noted above.}

During the scanning portion of the review, participants were asked" What could the FHWA do to help them do a better job of reducing delay and enhancing work zone safety?" Some of the suggestions were concepts and others were specific ways to accomplish a concept. The concepts were incorporated into various sections of this report. The following suggestions listed below are for FHWA program offices to consider:

\section{Education:}

C Develop talking papers/presentation materials on the benefits of work zone traffic management, time-based bidding; incentives for expediting contract completions; and work zone safety.

C Make a video for work zone traffic management, i.e., like the recent video with Chief Engineers on preventive maintenance.

C Facilitate quality improvement discussions for work zones ("Think Tanks" on this subject), possibly through the American Public Works Association's down-link program.

C Provide a comparison of the strengths, weaknesses, limitations, and correct application of existing software for predicting/calculating road-user cost, as well as delay, queues, and crashes in work zones.

C Maintain an up-to-date web site for approved safety hardware. 


\section{Contract Administration/Specifications:}

C Develop a generic performance-based specification for work zone traffic control.

C Develop guidance for incorporating a contractor's past performance (timely completion) into pre-qualification procedures.

C Develop a generic disincentive specification for contractors that do not remove work zone signs or that post erroneous messages on work zone signs. The message to contractors should be clear "you are accountable for what you tell the traveling public."

C Develop a congestion rental concept where the contractor takes responsibility for diverting traffic/traffic management.

\section{Signing, Pavement Markings, and the MUTCD:}

C Evaluate effectiveness of using "attention getting" signs in work zones, such as; “Speed Limit 45 - Fine is \$300," “Slow Down - 6 People Killed In This Work Zone,” and "Slow Down My Dad Works Here"(written in kid font).

C Change the "flagger" symbol on signs, brochures, etc., since the "Stop/Slow paddle" is in use today.

C Reevaluate the work zone signing requirements in Part VI of the MUTCD. "There are a lot of signs out there--do we still need all of them?"

C Revise the MUTCD to allow a "Last Exit Before Work Zone" sign for freeways. Also provide pull out/off areas for motorists to plan strategy.

C Develop a better way of identifying exit ramps in work zones.

C Challenge industry to develop a durable temporary pavement marking material that can be easily removed and does not leave a visible residue on the pavement.

C Revisit Federal prohibition of having a contractor's name posted on construction projects. [23 CFR 635.309(n)]

C Develop a work zone MUTCD that is tailored to utility companies.

C Experiment with colored symbol variable message signs (used by the Japanese and Europeans). 


\section{Enforcement:}

C Experiment with the use of holographic images of a trooper and/or incident at the beginning of a work zone.

C Develop a portable system to photograph vehicles and notify driver(s) that they are exceeding posted speeds.

\section{Worker Safety/Protection:}

C Develop a longitudinal safety barrier for mobile construction and maintenance operations performed on the road (something like an aircraft carrier catch net).

C Develop a longitudinal safety barrier for short-term maintenance operations performed adjacent to the shoulder.

C Develop a portable gawk screen for maintenance operations.

C Develop personal warning devices for workers, i.e., "credit card" size device (radio module or tag) that would be activated by an intrusion alarm system when a vehicle entered a safe zone. This device could also warn a worker when he/she left the safe zone, as well as activate a changeable message sign to notify motorists when the worker enters the travel lane(s).

C Explore DOD transponder technology that protects soldiers from friendly fire and apply it to workers in work zones.

C Use the machine vision capabilities of video cameras to detect vehicle intrusion and to signal workers through vibrating beepers.

C Develop a mechanized debris removal system.

C Develop a robotic crack cleaning/sealing system that uses crack recognition with an "ink-jet" type sealing device.

C Develop a mechanized full/partial-depth Portland Cement Concrete pavement patching device that eliminates the need for worker exposure.

\section{Awareness:}

C Conduct a follow-up survey/poll to the NQI Survey to find out what the public expects in work zones (urban and rural).

C Set up a work zone information display at State Fairs--maybe an interactive video and/or set up a work zone for people to walk through. 
C Establish a national symbol/logo (i.e., "Red Cross") for work zone safety which everyone would recognize.

C Post short work zone safety messages on the FHWA's Homepage. These messages would appear when the Homepage was brought up and would need to be changed periodically (daily or weekly).

C Establish partnerships with Internet search engines/browsers to place short work zone educational messages on their introductory index pages, i.e., Public Service Announcements on the Internet.

C Get major television networks to do a show and maybe a national television test on work zones, i.e., "60 Minutes," "Prime Time Live," “20/20,” and “Dateline," etc.

\section{Driver Education:}

C Develop generic up-to-date information on work zones that States could incorporate into their driver licensing manuals.

C Develop work zone modules for driver education classes. Develop a set of work zone questions that States could incorporate into their driver licensing tests.

C Develop an interactive video of driving though a work zone that could be used by driver education classes and/or as a video game.

\section{Motorist Information:}

C Establish a "Nationwide Work Zone Information Telephone Number," as a component part of the National Traveler Information System. The system should be menu driven to obtain work zone information by State and route.

C Obtain the Federal Communication Commission's approval of one acceptable frequency for Highway Advisory Radio. Present frequencies are not clear and many metropolitan areas are forced to use two or more frequencies on the same route.

C Experiment with the effectiveness of inductive radio messages (messages that will work whether radio is on or not) to warn drivers approaching major backups. 


\section{CONCLUSIONS}

Meeting the customers needs for mobility and safety during construction and maintenance operations is the heart of what the highway industry does and what it is all about ... planning, designing, constructing, rehabilitating, reconstructing, operating, and maintaining the highway system. What the motorist experiences in a work zone gets down to the very essence of what the highway industry is and what it does. It has been estimated that the majority of our nation's population travels through a work zone at least once every day. It is also estimated that over 80 percent of Federal-aid funds go into products that the public sees and experiences in work zones.

While there is no question that the quality of traffic control devices used in work zones and the uniformity of work zones has greatly improved since 1980, the total number of work zone fatalities has remained fairly constant since then. Because the previous focus and efforts have not significantly reduced the total number of work zone fatalities, it is only reasonable to assume, that with the substantial increase in funding levels provided in the TEA-21 coupled with the steady growth of traffic volumes on our aging highway system, the amount of delay and the number of work zones will sharply increase in the coming years with the potential for increased fatalities unless a significantly different approach and expanded efforts are taken to address work zones.

During the review the Review Team became acquainted with a number of isolated outstanding examples of work zone traffic management. However, work zone traffic management principles are not being applied to the majority of maintenance and construction operations. In order to significantly reduce motorist delays and crashes in work zones, transportation agencies must set a clear vision. This vision must be translated into performance objectives and traffic management integrated into the culture of the organization. Work zone traffic management principles must be applied through the life the project. Successful work zone traffic management is dependent upon reducing the exposure of the road user and the worker. Transportation agencies must focus on the bottom line; reducing the loss of life and limb, the waste of individuals' time, and the drain on our nation's economy. The road users have told the highway industry what they expect. Our vision is "No Delays and No Crashes in Work Zones." This vision can only be accomplished by integrating traffic management principles into the project development process (Table I) and applying these principles to every maintenance and construction operation. It is up to each of us to make the commitment to make a difference.

For the FHWA to achieve the strategic goals and objectives for safety, mobility, and productivity, the FHWA will have to assume a proactive leadership role in promoting work zone management techniques, dedicate the resources to develop and/or enhance the tools needed by the State and local transportation agencies to achieve the state of the art, create new partnerships for work zone education, and engage all of the stakeholders in a comprehensive cooperative effort. The road users have clearly stated their expectations for safety, quality, and, mobility. Our partners expect the FHWA to take a major leadership role. The time is right for the FHWA to step up to the plate and accept these challenges!

"The motorist measures our performance by what they experience in a work zone.' FHWA Official 


\section{Integration of Work Zone Traffic Management into the Project Development Process}

$\&$ Provide an organizational structure that facilitates cross-cutting teams

$\&$ Include public and other agencies in the development of the statewide policy

$\&$ Develop a statewide work zone traffic management policy

$\&$ Dedicate funds for preventive maintenance

$\&$ Collect and evaluate customer feedback

$\&$ Sponsor work zone traffic management training courses

$\&$ Facilitate public work zone educational and information programs

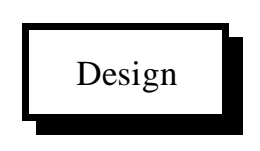

$\&$ Involve contractors in phasing the construction (+/- 30\% stage) $\&$ Develop alternate traffic control plans with cross-cutting teams

$\&$ Use computer modeling to evaluate alternate traffic control plans

$\&$ Involve public in selecting the project traffic control plan

$\&$ Use road-user costs and life-cycle cost in decisionmaking process

$\&$ Inclusion of high performance/low maintenance materials in the

$$
\text { design }
$$

\& Include additional features in design to mitigate traffic impacts of

future construction and maintenance operations

$\&$ Use value engineering

$\&$ Collect and analyze preconstruction delay and crash data

$\&$ Initiate traffic information program

$\&$ Include warrantees with bonuses in contracts

$\&$ Use performance based specifications to minimize traffic delays

$\&$ Use time based bidding procedures

\section{Degree of Influence on Reducing \\ Work Zone Delays and Enhancing Safety}

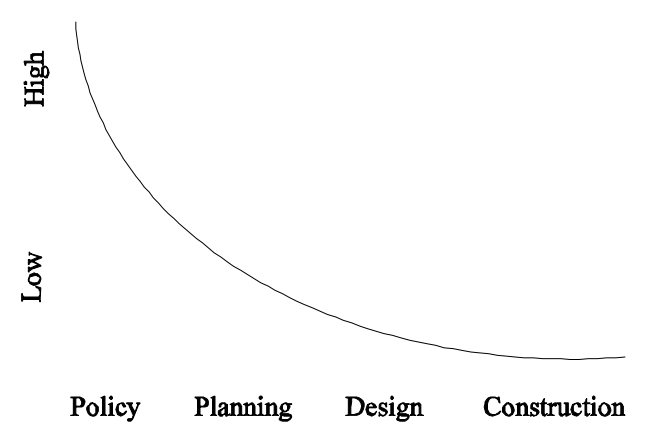

$\&$ Identify major traffic corridors

$\&$ Inventory long range capitol improvements

$\&$ Inventory preventive maintenance needs

$\&$ Identify alternate routes / modes in corridor

$\&$ Develop alternate corridor traffic management plans with crosscutting teams

\& Use computer modeling to evaluate alternate corridor traffic management plans

$\&$ Involve public in selecting the corridor traffic management plan $\&$ Use road-user costs and life-cycle costs in decisionmaking process

$\&$ Group and sequence projects to minimize exposure

$\&$ Conduct work zone traffic management training courses

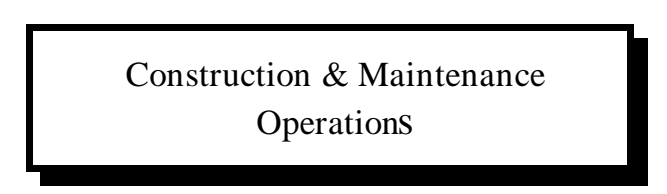

$\&$ Insist on quality work and timely completion of work $\&$ Continue traffic information program

$\&$ Use computer modeling to evaluate proposed changes to the traffic control plan

$\&$ Use road-user costs and life-cycle cost in decisionmaking process $\&$ Use uniformed police in the work zone

$\&$ Collect and disseminate real time traffic information

$\&$ Report and analyze all work zone crashes

$\&$ Encourage value engineering change proposals

$\&$ Reward innovations for reducing exposure to motorist

$\&$ Monitor delay and crash performance goals

$\&$ Pay contractor incentives for exceeding expectations

$\&$ Reward efficient maintenance operations 


\section{SUMMARY OF RECOMMENDATIONS}

\begin{tabular}{|c|c|c|c|}
\hline NUMBER & $\begin{array}{l}\text { SECTION } \\
\text { IN } \\
\text { REPORT }\end{array}$ & $\begin{array}{l}\text { PRODUCT } \\
\text { TEAMS TO } \\
\text { IMPLEMENT }\end{array}$ & RECOMMENDATION \\
\hline 1 & II $\mathrm{D} 1$ & Headquarters & $\begin{array}{l}\text { Partner with equipment manufactures to enhance the capabilities of Portable Traffic Management Systems and proactively } \\
\text { demonstrate the benefits of Portable Traffic Management Systems. }\end{array}$ \\
\hline 2 & II $\quad \mathrm{D} 1$ & Headquarters & $\begin{array}{l}\text { Develop and/or enhance user friendly software to model work zone delay, queues and crashes; calculate defendable road-user } \\
\text { cost and proposed contract time; evaluate proposed changes to the TCP as well as analyze work zone crashes. All software } \\
\text { must be sufficiently flexible to allow for variable parameters to meet unique State/local conditions. }\end{array}$ \\
\hline 3 & $\begin{array}{lll}\text { II } & \text { D } & 2 \\
\text { II } & \text { D } & 3\end{array}$ & $\begin{array}{l}\text { Headquarters } \\
\text { Resource Centers }\end{array}$ & $\begin{array}{l}\text { Develop and implement an ITS action plan of the activities required to achieve the state of the art by integrating ITS concepts } \\
\text { and technology into construction and maintenance operations. These activities include, but are not limited to, the production } \\
\text { of guidance materials, workshops, training courses, seminars, technical assistance programs, demonstrations, etc. }\end{array}$ \\
\hline 4 & II $\mathrm{D} 3$ & Headquarters & $\begin{array}{l}\text { Facilitate an organizational understanding of work zone traffic management versus traffic control. This includes integrating } \\
\text { traffic management principles into the early phases of the FHWA's Project Planning and NEPA Processes, developing a NHI } \\
\text { course on work zone traffic management, and updating the NHI work zone training courses by incorporating work zone traffic } \\
\text { management principles. }\end{array}$ \\
\hline 5 & II $\mathrm{D} 3$ & Headquarters & $\begin{array}{l}\text { Develop work zone education and awareness materials which can be tailored to individual State and local use. These include, } \\
\text { but are not limited to: preparation of work zone articles which can be used by the media, schools, national road-user } \\
\text { organizations, advocacy groups, and insurance companies. Promotion of an annual national work zone fatality free day, in } \\
\text { cooperation with the highway community, to highlight work zones. }\end{array}$ \\
\hline 6 & II $\quad \mathrm{D} 4$ & Headquarters & $\begin{array}{l}\text { Include work zones initiatives in the Annual Performance Plan. Establish work zone performance goals for delay and } \\
\text { fatalities such as: - A two percent reduction per year in fatalities in work zones, and } \\
\text { - A two percent reduction per year in construction time, motorist delay, and lane closure times. }\end{array}$ \\
\hline 7 & II $\mathrm{D} 5$ & Headquarters & $\begin{array}{l}\text { Develop active partnerships with national level organizations and the media (television, newspapers, magazines, etc.) to } \\
\text { provide focus, consolidate efforts in work zone awareness, marketing, education, and training. Disseminate work zone } \\
\text { educational materials. }\end{array}$ \\
\hline 8 & II $\mathrm{D} 6$ & Headquarters & $\begin{array}{l}\text { Develop, in cooperation with our partners, a national definition for work zones and standardize the work zone crash data that } \\
\text { is collected and reported. }\end{array}$ \\
\hline
\end{tabular}




\begin{tabular}{|c|c|c|c|}
\hline NUMBER & $\begin{array}{l}\text { SECTION } \\
\text { IN } \\
\text { REPORT }\end{array}$ & $\begin{array}{l}\text { PRODUCT } \\
\text { TEAMS TO } \\
\text { IMPLEMENT }\end{array}$ & RECOMMENDATION \\
\hline 9 & $\begin{array}{lll}\text { II } & \text { D } & 2 \\
\text { II } & \text { D } & 3\end{array}$ & Resource Centers & $\begin{array}{l}\text { Identify and disseminate work zone information through showcases, peer exchanges, and maintaining an up-to-date list of } \\
\text { work zone best policies/practices on the FHWA Home Page. Facilitate the sharing of work zone information by delivering } \\
\text { work zone training to meet State/local needs, conducting work zone workshops and assisting in the implementation of new } \\
\text { technology. }\end{array}$ \\
\hline 10 & II $\mathrm{D} 4$ & Resource Centers & Develop and implement long term initiatives that will achieve the state of the art. \\
\hline 11 & II $\mathrm{D} 6$ & $\begin{array}{l}\text { Resource Centers } \\
\text { and Divisions }\end{array}$ & $\begin{array}{l}\text { Improve the uniformity and consistency in work zone crash reporting. This includes but is not limited to partnering with the } \\
\text { State DOTs in providing training for State Police }\end{array}$ \\
\hline 12 & II $\mathrm{D} 2$ & Divisions & $\begin{array}{l}\text { Identify and proactively share best practices/policies that may solve the State's problems as well as assist in the } \\
\text { implementation of new technologies/best practices to reduce the road user's and the road worker's exposure in work zones. } \\
\text { Conduct annual listening sessions, with State DOTs, to solicit work zone technology needs. }\end{array}$ \\
\hline 13 & II $\mathrm{D} 3$ & Divisions & Promote, encourage, support, and partner with the State DOT in work zone educational outreach efforts. \\
\hline 14 & II $\mathrm{D} 4$ & Divisions & $\begin{array}{l}\text { Promote and proactively challenge the State DOT to adopt work zone performance goals for motorist delay and work zone } \\
\text { safety. }\end{array}$ \\
\hline 15 & II $\mathrm{D} 4$ & Divisions & $\begin{array}{l}\text { Identify one or more work zone initiatives in the Division's Annual Work Plan, to partner with State DOT's in reducing } \\
\text { motorist delay and enhancing work zone safety. }\end{array}$ \\
\hline 16 & II $\mathrm{D} 4$ & Divisions & Benchmark work zone practices/policies jointly with the State DOT. \\
\hline 17 & II D 5 & Divisions & $\begin{array}{l}\text { Take a proactive leadership role, in cooperation with the States, to foster partnerships at the State and local levels which focus } \\
\text { on reducing the exposure of road users and road workers. }\end{array}$ \\
\hline
\end{tabular}




\section{APPENDICES}




\section{APPENDIX "A"}

\section{Best Policies/Practices ${ }^{6}$ - Identified by the Transportation Agencies included in the Review To Minimize Delay and Enhance Safety During Construction and Maintenance Operations}

\begin{tabular}{|c|c|c|c|c|}
\hline PRACTICE & $\begin{array}{c}\text { CATEGORY } \\
\text { CROSS } \\
\text { REFERENCE }\end{array}$ & $\begin{array}{l}\text { STATE / } \\
\text { FHWA Region }\end{array}$ & CONTACT PEOPLE & TELEPHONE \\
\hline \multicolumn{5}{|l|}{ Category \# 1 - Policy (Direction/SOP) } \\
\hline Road Closure Program & & Arizona & $\begin{array}{l}\text { FHWA- Phil Bleyl } \\
\text { Maricopa County- Kent Hamm }\end{array}$ & $\begin{array}{l}(602) \\
(602) \\
506-46-3913\end{array}$ \\
\hline $\begin{array}{l}\text { Design and construction of City Water and Sewer Lines within the street right of way is done by the Street } \\
\text { Transportation Department }\end{array}$ & & Arizona & $\begin{array}{l}\text { FHWA - Phil Bleyl } \\
\text { City of Phoenix - Jim Sparks }\end{array}$ & 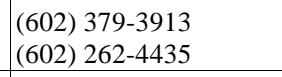 \\
\hline Street Closure Program & & Arizona & $\begin{array}{l}\text { FHWA -Phil Bleyl } \\
\text { City of Phoenix-Jim Sparks }\end{array}$ & 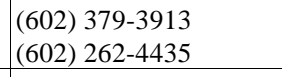 \\
\hline Caltrans Traffic Management Plan & & California & FHWA - G. P. Bill Wong & (916) 498-5042 \\
\hline Traffic Management Plan on major urban projects & & California & $\begin{array}{l}\text { Caltrans - Randall Iwasaki } \\
\text { Caltrans - Greg Edwards }\end{array}$ & $\begin{array}{l}(916) 654-5849 \\
(916) 654-3507\end{array}$ \\
\hline $\begin{array}{l}\text { "Design for Safety" Partnership (Design-construction-maintenance) formed to design projects to enhance worker } \\
\text { safety and minimize worker delays }\end{array}$ & & California & Caltrans- Jack Carr & (916) 654-5627 \\
\hline Long Life Pavement Rehabilitation Program for Urban Freeways & 7 & California & $\begin{array}{l}\text { FHWA - Steve Healow } \\
\text { Caltrans - Larry Orcutt }\end{array}$ & $\begin{array}{l}(916) 498-5849 \\
(916) 654-4792\end{array}$ \\
\hline Purchase of transit vehicles to reduce volume of automobiles through construction work zone & 7 & Colorado & $\begin{array}{l}\text { CDOT - Ralph Trapani } \\
\text { FHWA - Douglas Bennett }\end{array}$ & $\begin{array}{l}(970) 945-7629 \\
(303) 969-6730 \text { Ext } 373\end{array}$ \\
\hline Work zone performance measures for minimizing delay period/queue length & 7 & Florida & $\begin{array}{l}\text { FHWA - Bobby Norburn } \\
\text { FDOT - Rowland Lamb }\end{array}$ & 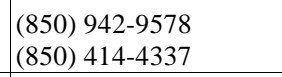 \\
\hline $\begin{array}{l}\text { Lane Closure Policy: On the Interstate (maintain the existing number of through travel lanes in the work area; in } \\
\text { no case less than two lanes) }\end{array}$ & & Florida & $\begin{array}{l}\text { FHWA - Bobby Norburn } \\
\text { FDOT- Rowland Lamb }\end{array}$ & 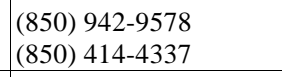 \\
\hline Round table discussions on urban freeway reconstruction and rehabilitation project issues & & Illinois & $\begin{array}{l}\text { IDOT - Jay Miller } \\
\text { FHWA - John Rohlf }\end{array}$ & $\begin{array}{l}(217) 785-0888 \\
(217) \\
492-4618\end{array}$ \\
\hline Mayor's Transportation Management Task Force & $4-8$ & Illinois & $\begin{array}{l}\text { City of Chicago - Thomas A. Smith } \\
\text { FHWA - J.D. Stokes }\end{array}$ & $\begin{array}{l}(312) \\
7124 \\
886-4684\end{array}$ \\
\hline INDOT Strategic Goal-Reduce Congestion in Work Zones & & Indiana & $\begin{array}{l}\text { FHWA - Ed Ratulowski } \\
\text { INDOT - Bob Cales }\end{array}$ & $\begin{array}{l}(317) 226-7342 \\
(317) 233-4792\end{array}$ \\
\hline Work zone baselines, benchmarks, and performance goals for fatalities and injuries & & Indiana & INDOT - John Nagle & (317) $232-5464$ \\
\hline Business Plan Strategy - Reduction of Businesses/Motorist Impact Due to Work Zones & $1-7$ & Maryland & $\begin{array}{l}\text { MdSHA - Doug Rose } \\
\text { MdSHA - Wayne Styles }\end{array}$ & $\begin{array}{l}\text { (410) } 545-0360 \\
(410)\end{array}$ \\
\hline
\end{tabular}

${ }^{6}$ A best practice/policy is any activity or policy or practice currently being used in your State that is effective in reducing motorist delay and/or enhancing the safety of current or future construction, maintenance, and/or utility work zones. 


\begin{tabular}{|c|c|c|c|c|}
\hline PRACTICE & $\begin{array}{c}\text { CATEGORY } \\
\text { CROSS } \\
\text { REFERENCE } \\
\end{array}$ & $\begin{array}{c}\text { STATE / } \\
\text { FHWA Region }\end{array}$ & CONTACT PEOPLE & TELEPHONE \\
\hline Twelve-Minute Delay Rule & & Massachusetts & $\begin{array}{l}\text { MHD - Charles F. Sterling } \\
\text { FHWA - Mike Graf }\end{array}$ & $\begin{array}{l}(617) 973-7360 \\
(617) 494-3359\end{array}$ \\
\hline "Office of Capital Project Safety" & & New Jersey & $\begin{array}{l}\text { FHWA - Gene Amparano } \\
\text { NJDOT - Anker Winther }\end{array}$ & $\begin{array}{l}(609) 637-4234 \\
(609) 530-5523\end{array}$ \\
\hline Limited length of lane closure within a project & & North Carolina & $\begin{array}{l}\text { NCDOT - Stuart Bourne } \\
\text { FHWA - Bradley Hibbs }\end{array}$ & $\begin{array}{l}\text { (919) } 250-4151 \\
(919) 856-4354\end{array}$ \\
\hline Policy/Standards for Slow Moving Maintenance Operations & & North Carolina & $\begin{array}{l}\text { NCDOT - Stuart Bourne } \\
\text { FHWA - Bradley Hibbs }\end{array}$ & $\begin{array}{l}\text { (919) } 250-4151 \\
(919) 856-4354\end{array}$ \\
\hline Lane Closure Policy/Map & 7 & Ohio & $\begin{array}{l}\text { ODOT - Dennis O’Neil } \\
\text { FHWA - Joe Glinski }\end{array}$ & $\begin{array}{l}\text { (216) } 581-2100 \text { Ext } 373 \\
\text { (614) } 280-6844\end{array}$ \\
\hline Weekend closures and total closures to accelerate work and minimize motorist delay & 7 & Ohio & City of Columbus - John Gallagher & (614) 645-3970 \\
\hline Life-cycle costing to select longer-lasting materials/products & & Ohio & ODOT - Dave Miller & (614) $275-1374$ \\
\hline "Compendium of Options" (Construction Traffic Maintenance Strategies) & & Ohio & $\begin{array}{l}\text { ODOT - Ken Linger } \\
\text { FHWA- Joe Glinski }\end{array}$ & $\begin{array}{l}(614) 466-0139 \\
(614) 280-6876\end{array}$ \\
\hline Full-Time Work Zone Traffic Control Person in Metro District Offices & & Ohio & $\begin{array}{l}\text { ODOT - Dennis O’Neil } \\
\text { FHWA - Joe Glinski }\end{array}$ & \begin{tabular}{|l}
$(216) 581-2100$ Ext \\
373 \\
$(614) 280-6844$
\end{tabular} \\
\hline Public-private partnership incentives for early completion & 7 & Oklahoma & $\begin{array}{l}\text { FHWA - Deanna Mills } \\
\text { ODOT - Jack Stewart }\end{array}$ & $\begin{array}{l}\text { (405) } 945-6172 \\
(405) 521-2625\end{array}$ \\
\hline Ramp closures during reconstruction & 7 & Oklahoma & $\begin{array}{l}\text { FHWA - Deanna Mills } \\
\text { ODOT - Christine Senkowski }\end{array}$ & $\begin{array}{l}(405) \text { 945-6172 } \\
(405) 521-2625 \\
\end{array}$ \\
\hline The specification for 20 minute maximum delay period & 7 & Oregon & $\begin{array}{l}\text { ODOT - Andy Anderson } \\
\text { FHWA - Anthony Boesen }\end{array}$ & $\begin{array}{l}(503) 986-3788 \\
(503) 587-4707\end{array}$ \\
\hline Performance Goal - Work Zones to be Designed at the Posted Speed & & Oregon & ODOT - Andy Anderson & (503) 986-3788 \\
\hline Use of commuter incentives to minimize congestion in work zones & 4 & Oregon & $\begin{array}{l}\text { FHWA - Jeff Graham } \\
\text { ODOT - Claude Sakr }\end{array}$ & $\begin{array}{l}(503) 587-4727 \\
(503) 641-7823\end{array}$ \\
\hline Minimum geometric standards for work zones & & Oregon & ODOT - Andy Anderson & (503) 986-3788 \\
\hline Business Plan Strategy -Reduce Work Zone Delays and Crashes & & Pennsylvania & $\begin{array}{l}\text { Penn DOT - Richard J. Sesny } \\
\text { FHWA - Michael J. Castellano }\end{array}$ & $\begin{array}{l}(717) 783-6080 \\
(717) 221-4517\end{array}$ \\
\hline $\begin{array}{l}\text { Policy--"Guidelines for Improving Safety in Freeway Construction Zone - " Work Zone Traffic Control } \\
\text { Congestion and Delay" - Congestion Reduction Work Zones }\end{array}$ & & Pennsylvania & $\begin{array}{l}\text { Penn DOT - Richard J. Sesny } \\
\text { FHWA - Michael J. Castellano }\end{array}$ & 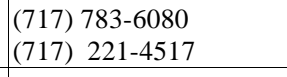 \\
\hline Multi-agency Work Zone Safety Committee (Trucking Assoc., State Police, PennDOT) & 2 & Pennsylvania & $\begin{array}{l}\text { Penn DOT - Richard J. Sesny } \\
\text { FHWA - Michael J. Castellano }\end{array}$ & $\begin{array}{l}(717) 783-6080 \\
(717) 221-4517\end{array}$ \\
\hline Removal of traffic control pattern if not working multiple shifts & 7 & Pennsylvania & $\begin{array}{l}\text { PTC- Timothy M. Scanlon } \\
\text { FHWA - Michael Castellano }\end{array}$ & $\begin{array}{l}\text { (717) } 939-9551 \text { Ext } \\
5590 \\
(717) 221-4517\end{array}$ \\
\hline Work zone safety program established by TxDOT & & Texas & TxDOT - Greg Brinkmeyer & (512) 416-3120 \\
\hline Policy--Balanced Transportation Program and Projects Advertised on Time & & Utah & $\begin{array}{l}\text { FHWA - Jeff Kolb } \\
\text { UDOT - Randy Lamoreaux }\end{array}$ & $\begin{array}{l}\text { (801) } 963-0078 \text { Ext. } 232 \\
(801) 965-4022\end{array}$ \\
\hline Motor Carrier Initiative- "Work Zone Accident Reduction/Prevention Project" & & Utah & $\begin{array}{l}\text { FHWA - Robert Kelleher } \\
\text { UDOT - Shirleen Hancock }\end{array}$ & $\begin{array}{l}\text { (801) } 963-0096 \text { Ext. } 247 \\
\text { (801) } 965-4781\end{array}$ \\
\hline One Season Construction Contracts & 7 & Utah & $\begin{array}{l}\text { FHWA - Jeff Kolb } \\
\text { UDOT - Tom Smith }\end{array}$ & $\begin{array}{l}\text { (801) 963-0078 Ext. } 232 \\
(801) 965-4403\end{array}$ \\
\hline
\end{tabular}




\begin{tabular}{|c|c|c|c|c|}
\hline PRACTICE & $\begin{array}{c}\text { CATEGORY } \\
\text { CROSS } \\
\text { REFERENCE }\end{array}$ & $\begin{array}{c}\text { STATE / } \\
\text { FHWA Region }\end{array}$ & CONTACT PEOPLE & TELEPHONE \\
\hline Lane Closure Coordinator for Interstate Highways in a State Highway District & 7 & Virginia & $\begin{array}{l}\text { FHWA - Robert F. McCarty } \\
\text { VDOT - Jane Peregoy }\end{array}$ & $\begin{array}{l}\text { (804) } 281-5109 \\
(703) 684-0923\end{array}$ \\
\hline Construction Work Zone Traffic Control Strategy & & Washington & $\begin{array}{l}\text { FHWA - Chuck Chappell } \\
\text { WSDOT - Jim Shanafelt }\end{array}$ & 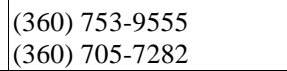 \\
\hline Work zone performance goal - 20 Minute Maximum Delay Specification & 7 & Wyoming & $\begin{array}{l}\text { WYDOT - Anthony (Bud) Schepp } \\
\text { FHWA - Larry Swanson }\end{array}$ & $\begin{array}{l}(307) 777-4491 \\
(307) 772-2004 \text { Ext. } 47\end{array}$ \\
\hline Guidelines for use of flaggers and police details for highway work zones & & Region 1 & FHWA - James A. Growney & (518) 431-4224 Ext 212 \\
\hline I-95 Corridor Coalition & 8 & $\begin{array}{l}\text { Region } 1 \text { - } \\
\text { Region } 3\end{array}$ & $\begin{array}{l}\text { FHWA- Al Alonzi } \\
\text { FHWA- Stephen Clinger }\end{array}$ & $\begin{array}{l}\text { (518) 431-4224 Ext } 228 \\
\text { (410) 962-0077 Ext } \\
3055\end{array}$ \\
\hline Accelerated Construction Initiative included in Region 3's FY 98 Work Plan & & Region 3 & FHWA - Joseph M. Huerta & $\begin{array}{l}(410) 962-0077 \text { Ext } \\
3056\end{array}$ \\
\hline Guidance - Uneven Pavement and Edge Drop-Off & & Region 4 & FHWA - Bernie Kuta & (404) 562-3685 \\
\hline Performance Plan Objective to reduce the public's exposure to highway construction activities & & Region 9 & FHWA - Wayne Kaneshiro & (415) 744-2662 \\
\hline \multicolumn{5}{|l|}{$\begin{array}{l}\text { Category \# } 2 \text { - Public Relations - Education - Out Reach } \\
\text { (General Public - Drivers - Policy Makers - Elected Officials) }\end{array}$} \\
\hline Constructing Your Image - A Public Relations Handbook for Contractors & 8 & Colorado & $\begin{array}{l}\text { CCA - Eldon Strong } \\
\text { CDOT - Dan Hopkins } \\
\text { FHWA - Douglas Bennett }\end{array}$ & $\begin{array}{l}\text { (303) } 290-6611 \\
(303) 757-9469 \\
(303) 969-6730 \text { Ext } 373\end{array}$ \\
\hline DOT personnel involved in driver education programs. & & Indiana & INDOT - Mike Hoffmann & (812) 522-5649 \\
\hline Public Information Campaign & 8 & Iowa & Iowa DOT - Jerry Dickinson & (515) 239-1667 \\
\hline Public outreach through use of neighborhood liaisons & 8 & Massachusetts & MHD - Andrew Paven & (617) $951-6120$ \\
\hline Media outreach program for construction and maintenance work zones & 8 & Mississippi & MDOT - Donna Lum & (601) 350-7017 \\
\hline TRANSCOM transmits to user groups & & New York & $\begin{array}{l}\text { FHWA - Mike Schauer } \\
\text { NYSDOT - Ed Roberts }\end{array}$ & $\begin{array}{l}\text { (518) } 431-4125 \text { Ext } 236 \\
\text { (518) } 457-1232\end{array}$ \\
\hline Public Awareness Committee/Public Education and Outreach Program for Work Zone Safety & 1 & North Carolina & $\begin{array}{l}\text { NCDOT- Jimmy Travis } \\
\text { FHWA - Bradley Hibbs }\end{array}$ & $\begin{array}{l}(919) 733-2210 \\
(919) 856-4354\end{array}$ \\
\hline Work Zone Safety Campaign -“Work Zone - Stay Alert” & & North Carolina & $\begin{array}{l}\text { NCDOT- Jimmy Travis } \\
\text { FHWA - Bradley Hibbs }\end{array}$ & $\begin{array}{l}\text { (919) } 733-2210 \\
(919) \\
856-4354\end{array}$ \\
\hline "IMPACT" - Public Information Program & & North Carolina & $\begin{array}{l}\text { NCDOT - Lisa M. Privette } \\
\text { FHWA - Bradley Hibbs }\end{array}$ & $\begin{array}{l}(919) 733-2210 \\
(919) 856-4354\end{array}$ \\
\hline Work Zone Safety video for truckers & & North Carolina & $\begin{array}{l}\text { NCDOT- Jimmy Travis } \\
\text { FHWA - Bradley Hibbs }\end{array}$ & $\begin{array}{l}(919) 733-2210 \\
(919) 856-4354\end{array}$ \\
\hline Work Zone Safety Public Service Announcement - "At the Office” & & North Carolina & $\begin{array}{l}\text { NCDOT- Jimmy Travis } \\
\text { FHWA - Bradley Hibbs }\end{array}$ & $\begin{array}{l}\text { (919) } 733-2210 \\
\text { (919) } 856-4354\end{array}$ \\
\hline Develop media partnerships & & Oregon & ODOT - Larry Christianson & (503) 986-4195 \\
\hline Public outreach efforts to increase participation in traffic management plan strategies & & Oregon & $\begin{array}{l}\text { FHWA - Jeff Graham } \\
\text { ODOT - Claude Sakr }\end{array}$ & $\begin{array}{l}\text { (503) } 587-4727 \\
(503) 641-7823\end{array}$ \\
\hline "Wizard" CB Radio transmissions providing work zone safety messages to truckers & & Pennsylvania & $\begin{array}{l}\text { Penn DOT - Richard J. Sesny } \\
\text { FHWA - Michael J. Castellano }\end{array}$ & $\begin{array}{l}\text { (717) } 783-6080 \\
\text { (717) } 221-4517 \\
\end{array}$ \\
\hline Partnership with Motor Truck Association & & Pennsylvania & $\begin{array}{l}\text { Penn DOT - Richard J. Sesny } \\
\text { FHWA - Michael J. Castellano }\end{array}$ & $\begin{array}{l}(717) 783-6080 \\
(717) 221-4517\end{array}$ \\
\hline
\end{tabular}




\begin{tabular}{|c|c|c|c|c|}
\hline PRACTICE & $\begin{array}{l}\text { CATEGORY } \\
\text { CROSS } \\
\text { REFERENCE }\end{array}$ & $\begin{array}{c}\text { STATE / } \\
\text { FHWA Region }\end{array}$ & CONTACT PEOPLE & TELEPHONE \\
\hline Fixed sign message “ $X X X$ People Killed in this Work Zone” displayed in advance of work zone & 7 & Pennsylvania & $\begin{array}{l}\text { Penn DOT - Richard J. Sesny } \\
\text { FHWA - Michael J. Castellano }\end{array}$ & $\begin{array}{l}(717) 783-6080 \\
(717) 221-4517\end{array}$ \\
\hline Work Zone Safety materials distributed at rest areas, welcome stations and truck stops & 8 & Pennsylvania & $\begin{array}{l}\text { Penn DOT - Richard J. Sesny } \\
\text { FHWA - Michael J. Castellano }\end{array}$ & $\begin{array}{l}\text { (717) } 783-6080 \\
(717) 221-4517 \\
\end{array}$ \\
\hline Work Zone Safety Week & & Virginia & $\begin{array}{l}\text { FHWA - Robert F. McCarty } \\
\text { VDOT - David Rush }\end{array}$ & $\begin{array}{l}\text { (804) } 281-5109 \\
(804) 371-6672\end{array}$ \\
\hline Joint training with contractor and VDOT construction/maintenance work zone personnel & & Virginia & $\begin{array}{l}\text { FHWA - Robert F. McCarty } \\
\text { VDOT - David Rush }\end{array}$ & $\begin{array}{l}(804) 281-5109 \\
(804) 371-6672\end{array}$ \\
\hline Work Zone Safety Round Tables & & Virginia & $\begin{array}{l}\text { FHWA - Robert F. McCarty } \\
\text { VDOT - David Rush }\end{array}$ & $\begin{array}{l}(804) \text { 281-5109 } \\
(804) 371-6672 \\
\end{array}$ \\
\hline "What's Wrong With This Work Zone" - training video & & Virginia & $\begin{array}{l}\text { FHWA - Robert F. McCarty } \\
\text { VDOT - David Rush }\end{array}$ & $\begin{array}{l}(804) 281-5109 \\
(804) 371-6672 \\
\end{array}$ \\
\hline Driver's Education: Learning Work Zone Safety & & Washington & WSDOT - Jennifer Marty & (360) 705-7079 \\
\hline Dissemination of work zone information & & Wyoming & $\begin{array}{l}\text { WYDOT - Anthony (Bud) Schepp } \\
\text { FHWA - Larry Swanson }\end{array}$ & $\begin{array}{l}(307) 777-4491 \\
(307) 772-2004 \text { Ext } 47\end{array}$ \\
\hline Quality Management Workshop & & Region 4 & FHWA - Bernie Kuta & (404) $562-3685$ \\
\hline Regional Work Zone Conferences & & Region 5 & FHWA - Dennis D. Lee & (708) 283-3554 \\
\hline Safety Regional Technical Specialty Team & & Region 5 & FHWA - Dennis D. Lee & (708) 283-3554 \\
\hline Promotion of A+B bidding; lane rentals; incentives/disincentives; PR campaign & & Region 6 & FHWA - Jerry Emerson & (817) 978-3926 \\
\hline Satellite video conference on work zone safety & & Region 6 & $\begin{array}{l}\text { FHWA - Jerry Emerson } \\
\text { APWA - Lillie Salinas }\end{array}$ & $\begin{array}{l}\text { (817) } 978-3926 \\
(816) 472-6100 \\
\end{array}$ \\
\hline "You Show Us How" Contests & & Region 8 & $\begin{array}{l}\text { FHWA - Bill Hakala } \\
\text { FHWA - Lloyd Rue } \\
\text { FHWA - Greg Schertz }\end{array}$ & $\begin{array}{l}\text { (303) } 969-5772 \text { Ext. } 339 \\
\text { (303) } 969-5772 \text { Ext. } 326 \\
\text { (303) } 969-5772 \text { Ext. } 342\end{array}$ \\
\hline Maintenance Tour & & Region 8 & FHWA - Bill Hakala & (303) 969-5772 Ext. 339 \\
\hline \multicolumn{5}{|l|}{ Category \# 3 - Prediction Modeling and impact Analysis: Congestion and Crashes } \\
\hline Lane closure analysis for toll roads & & Florida & \begin{tabular}{|l|} 
FHWA - Patrick Bauer \\
FDOT- (Turnpike) Kimberlee Poulton
\end{tabular} & $\begin{array}{l}(850) 942-9595 \\
(800) 749-7453 \\
\end{array}$ \\
\hline QUEWZ software is used to predict congestion and associated user costs & & Indiana & $\begin{array}{l}\text { FHWA - Ed Ratulowski } \\
\text { INDOT - David Boruff }\end{array}$ & $\begin{array}{l}(317) 226-7342 \\
(317) 232-5222 \\
\end{array}$ \\
\hline Modeling projected traffic delay & & Massachusetts & MHD - Glen Berkowitz & (617) 951-61131 \\
\hline Traffic Impact Report & & New Jersey & $\begin{array}{l}\text { FHWA - Gene Amparano } \\
\text { NJDOT- Timothy J. Szwedo } \\
\text { NJDOT - James Paral }\end{array}$ & $\begin{array}{l}(609) 637-4234 \\
(609) 530-2600 \\
(609) 530-2488 \\
\end{array}$ \\
\hline Traffic Impact Analysis & & Pennsylvania & $\begin{array}{l}\text { PTC- Timothy M. Scanlon } \\
\text { FHWA - Michael Castellano }\end{array}$ & $\begin{array}{l}\text { (717) 939-9551 Ext } 5590 \\
(717) 221-4517\end{array}$ \\
\hline $\begin{array}{l}\text { Tool--DELAY Enhanced 1.2 Software for Estimating User Delay Impacts and Costs for Freeway Capacity } \\
\text { Restrictions }\end{array}$ & & Utah & FHWA -Martin Knopp & (801) 963-0078 Ext. 236 \\
\hline
\end{tabular}




\begin{tabular}{|c|c|c|c|c|}
\hline PRACTICE & $\begin{array}{l}\text { CATEGORY } \\
\text { CROSS } \\
\text { REFERENCE }\end{array}$ & $\begin{array}{l}\text { STATE / } \\
\text { FHWA Region }\end{array}$ & CONTACT PEOPLE & TELEPHONE \\
\hline \multicolumn{5}{|l|}{ Category \# 4 - Planning and Programming } \\
\hline Corridor management approach for maintenance and construction operations & & California & $\begin{array}{l}\text { Caltrans - Bart Gauger } \\
\text { Caltrans - Randy Iwasaki }\end{array}$ & $\begin{array}{l}(916) 654-2157 \\
(916) 654-5849\end{array}$ \\
\hline Corridor planning used vs. project planning to minimize delays and enhance safety in work zones & & Indiana & $\begin{array}{l}\text { FHWA - Ed Ratulowski } \\
\text { INDOT - David Boruff } \\
\text { INDOT - Dan Shamo }\end{array}$ & $\begin{array}{l}(317) 226-7342 \\
(317) 232-5222 \\
(317) 232-5523\end{array}$ \\
\hline Traffic Management Plans (Chapter 81 in INDOT's Design Manual) & & Indiana & $\begin{array}{l}\text { FHWA - Ed Ratulowski } \\
\text { INDOT - David Boruff }\end{array}$ & $\begin{array}{l}(317) 226-7342 \\
(317) 232-5222\end{array}$ \\
\hline Corridor planning & & Michigan & $\begin{array}{l}\text { FHWA - Tom Fort } \\
\text { MDOT - Ernie Savas }\end{array}$ & $\begin{array}{l}\text { (517) } 377-1880 \text { Ext } 42 \\
(248) 483-5142\end{array}$ \\
\hline Comprehensive Traffic Management Plan for the reconstruction of the I-55/I-20 interchange & & Mississippi & MDOT - Donna Lum & (601) 350-7017 \\
\hline High Impact Project Task Forces & 5 & Missouri & $\begin{array}{l}\text { MoDOT -Bill Yarnell } \\
\text { MoDOT - Fred Martin } \\
\text { MoDOT - Ken Fryer } \\
\text { FHWA - Bob Thomas } \\
\end{array}$ & $\begin{array}{l}(573) 751-2876 \\
(573) 526-0093 \\
(573) 751-6602 \\
(573) 636-7104 \\
\end{array}$ \\
\hline Corridor Traffic Management Plans vs Project Traffic Control Plans & & Ohio & City of Columbus - John Gallagher & (614) 645-3970 \\
\hline $\begin{array}{l}\text { Coordination of all State DOT, local government, and utility construction and maintenance work to minimize } \\
\text { motorist delays in the Oklahoma City and Tulsa areas }\end{array}$ & 5 & Oklahoma & $\begin{array}{l}\text { FHWA - Deanna Mills } \\
\text { ODOT - S.C. "Pete" Byers }\end{array}$ & 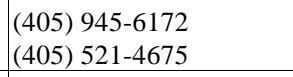 \\
\hline $\begin{array}{l}\text { Tool--Use of “MENUTP” Corridor Modeling for the Valley Concerning I-15 Construction Closure and } \\
\text { Restriction Alternatives }\end{array}$ & 3 & Utah & $\begin{array}{l}\text { FHWA - Harlan Miller } \\
\text { UDOT - John Leonard } \\
\text { WFRC - Mick Crandall }\end{array}$ & $\begin{array}{l}\text { (801) 963-0078 Ext. } 233 \\
(801) 594-6236 \\
(801) 299-5714\end{array}$ \\
\hline I-81 Steering Committee & & Virginia & $\begin{array}{l}\text { FHWA - Emily Lawton } \\
\text { VDOT - Jimmy Mills }\end{array}$ & $\begin{array}{l}(804) 281-5132 \\
(804) 786-2507\end{array}$ \\
\hline \multicolumn{5}{|l|}{ Category \# 5 - Project Development and Design } \\
\hline Traffic Management Workgroups & & Arizona & $\begin{array}{l}\text { FHWA - Phil Bleyl } \\
\text { ADOT - Mark Bonan }\end{array}$ & 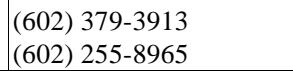 \\
\hline Involvement of affected communities and businesses in the project development process & & Arizona & $\begin{array}{l}\text { FHWA - Phil Bleyl } \\
\text { Maricopa County - Kent Hamm }\end{array}$ & $\begin{array}{l}(602) 379-3913 \\
(602) 506-4618\end{array}$ \\
\hline Formal Constructability Review Process & & California & $\begin{array}{l}\text { Caltrans - Jim Deluca } \\
\text { FHWA - Ken Kochevar }\end{array}$ & $\begin{array}{l}(916) 653-4067 \\
(916) 498-5853\end{array}$ \\
\hline Constructability reviews by construction industry representatives during project design & & Colorado & $\begin{array}{l}\text { CDOT - Tim Harris } \\
\text { FHWA - Douglas Bennett }\end{array}$ & $\begin{array}{l}\text { (303) } 757-9040 \\
\text { (303) } 969-6730 \text { Ext } 373\end{array}$ \\
\hline Constructability practices for reducing motorist and business exposure to the work zone & & Florida & $\begin{array}{l}\text { FHWA - Patrick Bauer } \\
\text { FDOT- John Shriner }\end{array}$ & 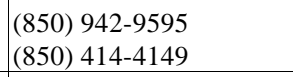 \\
\hline Utilizing video to enhance public involvement & & Illinois & $\begin{array}{l}\text { IDOT - George Ryan } \\
\text { FHWA - Keith Hoernschemeyer }\end{array}$ & $\begin{array}{l}(309) 671-3660 \\
(217) 492-4633\end{array}$ \\
\hline $\begin{array}{l}\text { Policy - Sequence, Coordinate and Schedule Projects to Minimize Motorist Delay and Interference to Affected } \\
\text { Business-Residential Community }\end{array}$ & 1 & Illinois & $\begin{array}{l}\text { City of Chicago - Thomas A. Smith } \\
\text { City of Chicago - Bruce Worthington } \\
\text { City of Chicago - Stan Kaderbek } \\
\text { FHWA - J. D. Stokes }\end{array}$ & $\begin{array}{l}(312) 744-4684 \\
(312) 744-3520 \\
(312) 744-3591 \\
(312) 886-1616\end{array}$ \\
\hline
\end{tabular}




\begin{tabular}{|c|c|c|c|c|}
\hline PRACTICE & $\begin{array}{l}\text { CATEGORY } \\
\text { CROSS } \\
\text { REFERENCE }\end{array}$ & \begin{tabular}{c|} 
STATE / \\
FHWA Region
\end{tabular} & CONTACT PEOPLE & TELEPHONE \\
\hline Road-user cost in evaluating and selecting traffic management plans & & Indiana & $\begin{array}{l}\text { FHWA - Ed Ratulowski } \\
\text { INDOT - David Boruff }\end{array}$ & $\begin{array}{l}(317) 226-7342 \\
(317) 232-5222\end{array}$ \\
\hline Multi-disciplinary teams to design, evaluate, and select traffic management plans & & Indiana & $\begin{array}{l}\text { FHWA - Ed Ratulowski } \\
\text { INDOT - Mike Holowaty }\end{array}$ & $\begin{array}{l}(317) 226-7342 \\
(317) 233-3016 \\
\end{array}$ \\
\hline $\begin{array}{l}\text { Comparisons of the estimated construction time required to maintain traffic through the work zone vs closing the } \\
\text { highway and diverting the traffic }\end{array}$ & & Indiana & INDOT - Brad Steckler & $(317) 232-5137$ \\
\hline Constructability reviews on high visibility projects in design phase & & Indiana & INDOT - Brad Steckler & (317) $232-5137$ \\
\hline Traffic Control Plan Checklist (Chapter 82-7 in INDOT’s Design Manual) & & Indiana & $\begin{array}{l}\text { FHWA - Ed Ratulowski } \\
\text { INDOT - Bob Cales }\end{array}$ & $\begin{array}{l}(317) 226-7342 \\
(317) 233-4792\end{array}$ \\
\hline $\begin{array}{l}\text { Comparison routinely made of the estimated construction time to maintain traffic through the work zone versus } \\
\text { the closing the highway and diverting the traffic }\end{array}$ & & Massachusetts & MHD - Glen Berkowitz & (617) 951-6131 \\
\hline Total road closure & 7 & Michigan & $\begin{array}{l}\text { FHWA - Dave Morena } \\
\text { MDOT - Bob Lariviere }\end{array}$ & \begin{tabular}{|l}
$(517) 377-1880$ Ext 35 \\
$(248)$ \\
$483-5100$ Ext 210
\end{tabular} \\
\hline North Carolina Contractor's Association participation in constructability reviews & & North Carolina & $\begin{array}{l}\text { NCDOT -Steve DeWitt } \\
\text { FHWA - Bradley Hibbs }\end{array}$ & $\begin{array}{l}(919) 733-2210 \\
(919) 856-4354\end{array}$ \\
\hline “Coordination of Road Closure/Detours During Construction” - Design Procedures Manual & 7 & North Carolina & $\begin{array}{l}\text { NCDOT - Stuart Bourne } \\
\text { FHWA - Bradley Hibbs }\end{array}$ & $\begin{array}{l}(919) \text { 250-4151 } \\
(919) 856-4354\end{array}$ \\
\hline Community Advisory Councils & & Ohio & City of Columbus - John Gallagher & (614) 645-3970 \\
\hline Contractor participation in constructability reviews & & Oklahoma & $\begin{array}{l}\text { FHWA - Deanna Mills } \\
\text { ODOT - Jack Stewart }\end{array}$ & 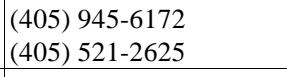 \\
\hline CPM scheduling to set contract time & & Oklahoma & $\begin{array}{l}\text { FHWA - Deanna Mills } \\
\text { ODOT - Christine Senkowski }\end{array}$ & $\begin{array}{l}(405) \\
(405) \\
521-2625\end{array}$ \\
\hline $\begin{array}{l}\text { Value-engineering studies are conducted on major projects in the early phases of design and focus on traffic } \\
\text { management }\end{array}$ & & Texas & TxDOT - Mark Marek & (512) 416-2653 \\
\hline $\begin{array}{l}\text { Emergency Response Team and Trucking Association involved in the design/evaluation of the traffic control } \\
\text { plan }\end{array}$ & & Utah & $\begin{array}{l}\text { FHWA - Robert Kelleher } \\
\text { UHP - Sgt. Danny Catlin }\end{array}$ & $\begin{array}{l}(801) 963-0096 \text { Ext } 247 \\
(801) 965-4676\end{array}$ \\
\hline Contractor hired by the design consultant to do constructability review on James River Bridge & & Virginia & $\begin{array}{l}\text { FHWA - Emily Lawton } \\
\text { VDOT - Larry Jones }\end{array}$ & $\begin{array}{l}(804) 281-5132 \\
(804) 786-7712 \\
\end{array}$ \\
\hline Value-engineering (all projects over $\$ 2$ million) to minimize construction time and road-user cost & & Virginia & $\begin{array}{l}\text { FHWA - Emily Lawton } \\
\text { VDOT - Frank Gee }\end{array}$ & $\begin{array}{l}(804) 281-5132 \\
(804) 786-2785\end{array}$ \\
\hline Methods of Reducing Work Zone Congestion “Tool Box” & & Washington & $\begin{array}{l}\text { FHWA- Chuck Chappell } \\
\text { WSDOT - Jim Shanafelt }\end{array}$ & $\begin{array}{l}(360) 753-9555 \\
(360) 705-7282\end{array}$ \\
\hline \multicolumn{5}{|l|}{ Category \# 6 - Contracting and Bidding Procedures } \\
\hline Alternative Contracting Practices & & Florida & $\begin{array}{l}\text { FHWA - Patrick Bauer } \\
\text { FDOT- Jimmy Lairscey }\end{array}$ & $\begin{array}{l}(850) \text { 942-9595 } \\
(850) 414-4116 \\
\end{array}$ \\
\hline Flexible Start Times & & Florida & $\begin{array}{l}\text { FHWA - Patrick Bauer } \\
\text { FDOT Jimmy Lairscey }\end{array}$ & $\begin{array}{l}(850) \text { 942-9595 } \\
(850) 414-4116\end{array}$ \\
\hline Summertime Bridge Reconstruction Program & & Georgia & $\begin{array}{l}\text { FHWA - Ted Burch } \\
\text { Cobb County - James Croy }\end{array}$ & $\begin{array}{l}\text { (404) } 562-3643 \\
(770) 528-1608 \\
\end{array}$ \\
\hline $\mathrm{A}+\mathrm{B}, \mathrm{I} / \mathrm{D}$ and Lane Rental in reducing contract time & & Indiana & INDOT - Timothy Bertram & (317) 232-5502 \\
\hline
\end{tabular}




\begin{tabular}{|c|c|c|c|c|}
\hline PRACTICE & $\begin{array}{l}\text { CATEGORY } \\
\text { CROSS } \\
\text { REFERENCE }\end{array}$ & $\begin{array}{c}\text { STATE / } \\
\text { FHWA Region }\end{array}$ & CONTACT PEOPLE & TELEPHONE \\
\hline $\mathrm{A}+\mathrm{B}$, and Incentive/Disincentive clauses & & Michigan & $\begin{array}{l}\text { FHWA - Tom Fort } \\
\text { MDOT - John Lavoy }\end{array}$ & $\begin{array}{l}\text { (517) } 377-1880 \text { Ext } 42 \\
\text { (517) } 373-2301\end{array}$ \\
\hline Time Based Bidding (A+B, I/D, and Lane Rental) & & Mississippi & MDOT - Thomas Russell & (601) 359-7301 \\
\hline Contractor Rating System & & Missouri & $\begin{array}{l}\text { MoDOT - Ken Fryer } \\
\text { FHWA - Bob Thomas }\end{array}$ & $\begin{array}{l}(573) 751-6602 \\
(573) 636-7104\end{array}$ \\
\hline $\mathrm{A}+\mathrm{B}$ with $\mathrm{I} / \mathrm{D}$ for reducing contract time & & Missouri & $\begin{array}{l}\text { MoDOT - Connie Baldwin } \\
\text { MoDOT - Diane Heckemeyer }\end{array}$ & $\begin{array}{l}(573) 751-6602 \\
(573) 346-3053\end{array}$ \\
\hline$A+B$ contracts & 11 & New York & $\begin{array}{l}\text { NYSDOT - Richard W. Lee } \\
\text { FHWA - Thomas Herritt }\end{array}$ & $\begin{array}{l}\text { (518) } 457-4449 \\
\text { (518) } 431-4125 \text { Ext } 233\end{array}$ \\
\hline A+B Bidding Clauses in North Carolina DOT contracts & & North Carolina & $\begin{array}{l}\text { NCDOT -Steve DeWitt } \\
\text { FHWA - Bradley Hibbs }\end{array}$ & 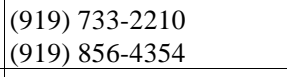 \\
\hline $\begin{array}{l}\text { Pre-qualification to restrict the bidding capacity of contractors who were behind schedule on current DOT } \\
\text { contracts or who consistently demonstrated their inability to complete DOT contracts on schedule. }\end{array}$ & & Ohio & ODOT - Mark Kelsey & (614) 466-3778 \\
\hline Construction lane-mile rentals & & Oklahoma & FHWA - Deanna Mills & (405) 945-6172 \\
\hline Lane rental & & Oklahoma & $\begin{array}{l}\text { FHWA - Deanna Mills } \\
\text { ODOT - Jack Stewart }\end{array}$ & $\begin{array}{l}(405) \\
945-6172 \\
(405) 521-2625\end{array}$ \\
\hline Flexible start time provisions in contract & & Oklahoma & $\begin{array}{l}\text { FHWA - Deanna Mills } \\
\text { ODOT - Jack Stewart }\end{array}$ & $\begin{array}{l}(405) \\
945-6172 \\
(405) 521-2625\end{array}$ \\
\hline A+B Bidding (Time-Based Bidding) & & Oklahoma & $\begin{array}{l}\text { FHWA - Deanna Mills } \\
\text { ODOT - Jack Stewart }\end{array}$ & 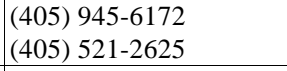 \\
\hline Lane Rental specification & & Oregon & $\begin{array}{l}\text { ODOT - Tom Lauer } \\
\text { FHWA - John Gernhauser }\end{array}$ & $\begin{array}{l}(503) \\
986-2631 \\
(503) 587-4708\end{array}$ \\
\hline Contract award of the I-5 Interstate bridge lift span repair project based on performance and cost & & Oregon & $\begin{array}{l}\text { FHWA - Jeff Graham } \\
\text { ODOT - Claude Sakr }\end{array}$ & $\begin{array}{l}(503) 587-4727 \\
(503) 641-7823\end{array}$ \\
\hline Narrow window for on-site construction & & Oregon & $\begin{array}{l}\text { ODOT - Ken Stoneman } \\
\text { FHWA - John Gernhauser }\end{array}$ & $\begin{array}{l}(503) 986-3023 \\
(503) 587-4708\end{array}$ \\
\hline Frequent use of innovative contracting procedures & & Utah & FHWA - Jeff Kolb & (801) 963-0078 Ext 232 \\
\hline \multicolumn{5}{|l|}{ Category \# 7 - Specifications and Construction Materials, Methods, and Practices } \\
\hline Disincentive specification for failure to remove lane closures by the prescribed time each day & & California & Caltrans - Bob Finny & (510) 286-0947 \\
\hline Reflectorized suits for nighttime work & & California & Caltrans- Jack Carr & (916) 654-5627 \\
\hline Incident management in work zones & & California & Caltrans- Jack Carr & (916) 654-5627 \\
\hline Quick Change sign post & & California & $\begin{array}{l}\text { Caltrans - Mike White } \\
\text { FHWA - Eric Steavens }\end{array}$ & $\begin{array}{l}(916) 227-7076 \\
(916) 498-5861\end{array}$ \\
\hline Portable concrete barrier (K-rail) connection & & California & Caltrans- Jack Carr & (916) 654-5627 \\
\hline "Train" method of construction & & Florida & $\begin{array}{l}\text { FHWA - Patrick Bauer } \\
\text { FDOT- Jimmy Lairscey }\end{array}$ & 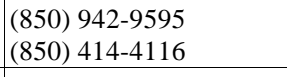 \\
\hline "Rolling Roadblock" - method for total road closure & & Florida & $\begin{array}{l}\text { FHWA - Mr. Bobby Norburn } \\
\text { FDOT- Rowland Lamb } \\
\text { FDOT (Turnpike) - Bill Heiman }\end{array}$ & $\begin{array}{l}(850) 942-9578 \\
(850) 414-4337 \\
(850) 488-4671\end{array}$ \\
\hline $\begin{array}{l}\text { Use of the Orlando Traffic Control Center/Surveillance \& Motorist Information System (SMIS) during } \\
\text { construction projects }\end{array}$ & & Florida & $\begin{array}{l}\text { FHWA - Grant Zammit } \\
\text { FDOT - Jon Cheney }\end{array}$ & $\begin{array}{l}(850) 942-9693 \\
(904) 943-5322\end{array}$ \\
\hline
\end{tabular}




\begin{tabular}{|c|c|c|c|c|}
\hline PRACTICE & $\begin{array}{l}\text { CATEGORY } \\
\text { CROSS } \\
\text { REFERENCE }\end{array}$ & $\begin{array}{c}\text { STATE / } \\
\text { FHWA Region }\end{array}$ & CONTACT PEOPLE & TELEPHONE \\
\hline All lane closures are approved by the Authority & & Illinois & $\begin{array}{l}\text { Toll Authority - John Wagner } \\
\text { FHWA - Daniel Mathis }\end{array}$ & $\begin{array}{l}\text { (630) 241-6800 Ext } 3934 \\
(217) 492-4641\end{array}$ \\
\hline $\begin{array}{l}\text { Standard specification that requires the contractor to correct deficient traffic control at the Engineer's request or } \\
\text { be subject to a } \$ 500 \text { penalty }\end{array}$ & & Illinois & $\begin{array}{l}\text { Toll Authority - John Wagner } \\
\text { FHWA - Daniel Mathis }\end{array}$ & $\begin{array}{l}\text { (630) } 241-6800 \text { Ext } 3934 \\
(217) 492-4641\end{array}$ \\
\hline Emergency Traffic Patrol motorist assistance and incident management program & & Illinois & $\begin{array}{l}\text { IDOT - John Mitchell } \\
\text { FHWA - Pete Olson }\end{array}$ & $\begin{array}{l}(773) 624-0470 \\
(217) 492-4634 \\
\end{array}$ \\
\hline $45 \mathrm{mph}$ posted speed when flashing & & Indiana & INDOT - Frank Vucovits & (317) $232-5507$ \\
\hline High visibility worker apparel & & Iowa & Iowa DOT - Barb Mallon & (515) 239-1594 \\
\hline Project monitoring with incident response & & Iowa & Iowa DOT - Mark Bortle & (515) 239-1587 \\
\hline Employ a part-time retired bridge contractor to assist designers and to perform constructability reviews & 11 & Maryland & MdSHA - Robert J. Healy & (410) 545-8063 \\
\hline Extended warranty specification for bridge painting contracts & & Maryland & MdSHA - Paul E. Perkins & (410) $787-8372$ \\
\hline Dispute Resolution Process Agreement for changes to traffic control plan between CA/T and City of Boston & 1 & Massachusetts & MHD - Glen Berkowitz & (617) 951-61131 \\
\hline City of Boston Traffic Engineers included on CA/T Traffic Engineering staff & 1 & Massachusetts & MHD - Glen Berkowitz & (617) $951-61131$ \\
\hline Restricting the length of active work zones & & Mississippi & MDOT - Thomas Russell & (601) $359-7301$ \\
\hline 14-foot lane width pavements for all rehabilitation/reconstruction projects & & Mississippi & MDOT - John Pickering & (601) $359-7257$ \\
\hline Incident management Special Provision in Construction Contracts & & Mississippi & MDOT - Donna Lum & (601) $350-7017$ \\
\hline Diamond grinding finish profile on PCC pavements ("White Velvet Pavement”) & & Missouri & $\begin{array}{l}\text { MoDOT - Bill Yarnell } \\
\text { MoDOT - Lindell Huskey } \\
\text { FHWA - Mike Staggs }\end{array}$ & \begin{tabular}{|l} 
(573) $751-2876$ \\
$(573) 840-9781$ \\
$(573) 636-7104$ \\
\end{tabular} \\
\hline $\begin{array}{l}\text { A "Safety Program" specification has been recently developed by the NJDOT and accepted by the construction } \\
\text { industry }\end{array}$ & & New Jersey & $\begin{array}{l}\text { FHWA - Gene Amparano } \\
\text { NJDOT - Anker Winther }\end{array}$ & $\begin{array}{l}(609) 637-4234 \\
(609) 530-5523\end{array}$ \\
\hline NJDOT Nighttime Lighting Specification for night work & & New Jersey & $\begin{array}{l}\text { FHWA - Gene Amparano } \\
\text { NJDOT - Michael W. Gross }\end{array}$ & 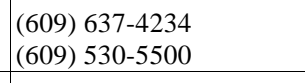 \\
\hline Nighttime construction operations & & New York & NYSDOT - Chuck Riedel & (518) 457-3537 \\
\hline Incident management inter-agency teams & & North Carolina & $\begin{array}{l}\text { NCDOT - Cheryl Evans } \\
\text { FHWA - Bradley Hibbs }\end{array}$ & $\begin{array}{l}\text { (919) } 733-2210 \\
(919) 856-4354 \\
\end{array}$ \\
\hline Portable lighting specified in contracts containing critical lane closures and/or merges & & North Carolina & $\begin{array}{l}\text { NCDOT - Stuart Bourne } \\
\text { FHWA - Bradley Hibbs }\end{array}$ & \begin{tabular}{|l|} 
(919) $250-4151$ \\
(919) $856-4354$ \\
\end{tabular} \\
\hline Closure of entrance ramps during construction & & Ohio & City of Columbus - John Gallagher & (614) 645-3970 \\
\hline Drone radar on changeable message signs approaching work zones to get the driver's attention & 10 & Ohio & $\begin{array}{l}\text { ODOT - Dennis O’Neil } \\
\text { FHWA - Joe Glinski }\end{array}$ & $\begin{array}{l}\text { (216) 581-2100 Ext } 373 \\
\text { (614) } 280-6844\end{array}$ \\
\hline Rumble strips at the beginning of work zones to get the driver's attention & & Ohio & $\begin{array}{l}\text { ODOT - Dennis O’Neil } \\
\text { FHWA - Joe Glinski }\end{array}$ & $\begin{array}{l}\text { (216) 581-2100 Ext } 373 \\
\text { (614) 280-6844 }\end{array}$ \\
\hline Certified Worksite Traffic Control Supervisors required in contracts & & Ohio & $\begin{array}{l}\text { ODOT - Dennis O’Neil } \\
\text { FHWA - Joe Glinski }\end{array}$ & $\begin{array}{l}\text { (216) 581-2100 Ext } 373 \\
\text { (614) } 280-6844\end{array}$ \\
\hline Incident Management in the Westside Corridor work zones & & Oregon & $\begin{array}{l}\text { FHWA - Jeff Graham } \\
\text { ODOT - Claude Sakr }\end{array}$ & $\begin{array}{l}\text { (503) } 587-4727 \\
(503) 641-7823 \\
\end{array}$ \\
\hline Monitoring of the contractor's Critical Path Method (CPM) schedule & & Oregon & FHWA - Roger Harding & (503) 587-4711 \\
\hline Motorist Services & & Pennsylvania & $\begin{array}{l}\text { Penn DOT - Richard J. Sesny } \\
\text { FHWA - Michael J. Castellano }\end{array}$ & $\begin{array}{l}(717) 783-6080 \\
(717) 221-4517\end{array}$ \\
\hline Highly visible reflectorized flagger vest (strong yellow green \& orange) & & Pennsylvania & $\begin{array}{l}\text { Penn DOT - Richard J. Sesny } \\
\text { FHWA - Michael J. Castellano }\end{array}$ & $\begin{array}{l}\text { (717) } 783-6080 \\
(717) 221-4517\end{array}$ \\
\hline
\end{tabular}




\begin{tabular}{|c|c|c|c|c|}
\hline PRACTICE & $\begin{array}{l}\text { CATEGORY } \\
\text { CROSS } \\
\text { REFERENCE } \\
\end{array}$ & $\begin{array}{c}\text { STATE / } \\
\text { FHWA Region }\end{array}$ & CONTACT PEOPLE & TELEPHONE \\
\hline $\begin{array}{l}\text { An incident management plan is required on long-term construction projects - Freeway projects normally require } \\
\text { a preconstruction meeting with emergency responders }\end{array}$ & & Pennsylvania & $\begin{array}{l}\text { Penn DOT - Richard J. Sesny } \\
\text { FHWA - Michael J. Castellano }\end{array}$ & $\begin{array}{l}(717) 783-6080 \\
(717) 221-4517\end{array}$ \\
\hline Contractor-furnished Service Patrols on the I-15 project & & Utah & $\begin{array}{l}\text { FHWA - Jeff Kolb } \\
\text { UDOT - John Leonard }\end{array}$ & $\begin{array}{l}(801) 963-0078 \text { Ext. } 232 \\
(801) 594-6236\end{array}$ \\
\hline 10 Year Warranty (maintenance provision) for I- 15 & & Utah & $\begin{array}{l}\text { FHWA - Jeff Kolb } \\
\text { UDOT - David Downs }\end{array}$ & $\begin{array}{l}\text { (801) 963-0078 Ext. } 232 \\
\text { (801) 594-6364 }\end{array}$ \\
\hline Work zone incident management provisions in construction contracts & & Utah & $\begin{array}{l}\text { UDOT - John Leonard } \\
\text { FHWA - Greg Punske }\end{array}$ & $\begin{array}{l}(801) 594-6236 \\
\text { (801) } 963-0078 \text { Ext. } 237\end{array}$ \\
\hline Flagger Certification Program & & Virginia & $\begin{array}{l}\text { FHWA - Robert F. McCarty } \\
\text { VDOT - David Rush }\end{array}$ & $\begin{array}{l}(804) \\
(804) \\
(871-6672\end{array}$ \\
\hline "Work Zone Safety Checklist" Form & & Virginia & $\begin{array}{l}\text { FHWA - Robert F. McCarty } \\
\text { VDOT - David Rush }\end{array}$ & 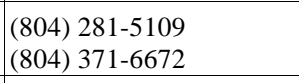 \\
\hline Pocket size "Guidelines For Temporary Traffic Control" & & Virginia & $\begin{array}{l}\text { FHWA - Robert F. McCarty } \\
\text { VDOT - David Rush }\end{array}$ & $\begin{array}{l}(804) 281-5109 \\
(804) 371-6672\end{array}$ \\
\hline Constructability reviews focused on minimizing construction contract time and user delays & & Virginia & $\begin{array}{l}\text { FHWA - Robert F. McCarty } \\
\text { VDOT - J. T. Mills }\end{array}$ & $\begin{array}{l}(804) \text { 281-5109 } \\
(804) 786-2507\end{array}$ \\
\hline Temporary High Mast Lighting & & Washington & WSDOT - Frank R. Newboles & (360) $357-2687$ \\
\hline \multicolumn{5}{|l|}{ Category \# 8 - Traveler and Traffic Information ( Project Related) } \\
\hline Construction Project Public Information/Public Relations Program (Newsletters) & & Arizona & $\begin{array}{l}\text { FHWA - Phil Bleyl } \\
\text { ADOT - Mark Bonan, } \\
\text { ADOT - Dennis Alvarez }\end{array}$ & $\begin{array}{l}(602) 379-3913 \\
(602) 255-8965 \\
(520) 620-5427\end{array}$ \\
\hline Bid item in the construction contract for public relations & & Arizona & $\begin{array}{l}\text { FHWA - Phil Bleyl } \\
\text { Maricopa County - Kent Hamm }\end{array}$ & 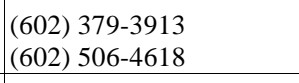 \\
\hline Signing for businesses affected by the construction of city streets & & Arizona & $\begin{array}{l}\text { FHWA - Phil Bleyl } \\
\text { City of Phoenix - Jim Sparks }\end{array}$ & $\begin{array}{l}(602) \\
(602) \\
(679-392-4435\end{array}$ \\
\hline District Work Zone Traffic Management Coordinator & 1 & California & $\begin{array}{l}\text { Caltrans- Jack Carr } \\
\text { Caltrans - Randy Ronning }\end{array}$ & $\begin{array}{l}(916) 654-5627 \\
(916) 654-7312\end{array}$ \\
\hline Dissemination of work zone project information by Public Information Offices & & Florida & $\begin{array}{l}\text { FHWA - Bobby Norburn } \\
\text { FDOT- Mr. Charles Goodman }\end{array}$ & $\begin{array}{l}(850) \text { 942-9578 } \\
(850) \text { 414-4150 }\end{array}$ \\
\hline Georgia NAVIGATOR (WWW.GEORGIA-NAVIGATOR.COM) & & Georgia & $\begin{array}{l}\text { FHWA - Ted Burch } \\
\text { GDOT- Ben Snedeker }\end{array}$ & $\begin{array}{l}(404) 562-3643 \\
(404) 635-8018 \\
\end{array}$ \\
\hline Public relation campaigns and the use of public relation firms & & Illinois & $\begin{array}{l}\text { IDOT - Dick Adorjan } \\
\text { FHWA - John Rohlf }\end{array}$ & $\begin{array}{l}(217) 782-6953 \\
(217) 492-4618\end{array}$ \\
\hline $\begin{array}{l}\text { Public relations campaign for Illinois State Toll Highway Authority (ISTHA) construction and maintenance } \\
\text { projects in the Chicago metro area }\end{array}$ & & Illinois & $\begin{array}{l}\text { Toll Authority - Kesti Susinskas } \\
\text { FHWA - Daniel Mathis }\end{array}$ & $\begin{array}{l}\text { (630) 241-6800 Ext } 3901 \\
\text { (217) } 492-4641\end{array}$ \\
\hline Provide real-time traffic information to the public & & Illinois & $\begin{array}{l}\text { IDOT - John Koziol } \\
\text { IDOT - Tony Cioffi } \\
\text { FHWA - Pete Olson` }\end{array}$ & $\begin{array}{l}(847) 705-4561 \\
(708) 524-2145 \\
(217) 492-4634 \\
\end{array}$ \\
\hline Media partnership to inform public of traffic affected by construction and maintenance operations & & Illinois & $\begin{array}{l}\text { City of Chicago - Craig Wolf } \\
\text { City of Chicago - Matt Smith } \\
\text { FHWA - J.D. Stokes }\end{array}$ & $\begin{array}{l}(312) 744-0707 \\
(312) 744-7261 \\
(312) 886-1616\end{array}$ \\
\hline Hoosier Helper & & Indiana & INDOT - Dan Shamo & (317) 232-5523 \\
\hline
\end{tabular}




\begin{tabular}{|c|c|c|c|c|}
\hline PRACTICE & $\begin{array}{l}\text { CATEGORY } \\
\text { CROSS } \\
\text { REFERENCE }\end{array}$ & $\begin{array}{c}\text { STATE / } \\
\text { FHWA Region }\end{array}$ & CONTACT PEOPLE & TELEPHONE \\
\hline Media to minimize work zone delays and inform public of work zone delays & & Indiana & $\begin{array}{l}\text { FHWA - Ed Ratulowski } \\
\text { INDOT - Chris Baynes } \\
\text { INDOT - Roger Manning }\end{array}$ & $\begin{array}{l}(317) 226-7342 \\
(317) 232-5116 \\
(317) 233-4675\end{array}$ \\
\hline Joint Approval Form ( CA/T and City of Boston ) for Traffic Advisories and Alerts & $1-7$ & Massachusetts & MHD - Glen Berkowitz & (617) $951-61131$ \\
\hline Web Site for Traffic Information, Advisories and Alerts ( http:www.bigdig.com/traffic.htm ) & & Massachusetts & $\begin{array}{l}\text { MHD - Terry Brown } \\
\text { MHD - Brian Baker }\end{array}$ & $\begin{array}{l}(617) 951-6183 \\
(617) 951-6400\end{array}$ \\
\hline Traveler's Information Kiosks in Rest Areas - Work Zones & & Mississippi & MDOT - Donna Lum & (601) $350-7017$ \\
\hline Use of INFORM to advise motorists of work zone delays & & New York & $\begin{array}{l}\text { FHWA - Mike Schauer } \\
\text { NYSDOT - Ed Roberts }\end{array}$ & $\begin{array}{l}\text { (518) } 431-4125 \text { Ext } 236 \\
\text { (518) } 457-1232\end{array}$ \\
\hline "Paving the Way" & & Ohio & City of Columbus - John Gallagher & (614) 645-3970 \\
\hline "Fax on Demand" traffic information & & Ohio & City of Columbus - John Gallagher & (614) 645-3970 \\
\hline Media partnership to reduce the volume of traffic through the work zone & & Ohio & City of Columbus - John Gallagher & (614) 645-3970 \\
\hline Contractor involvement in public information meetings and lane closure notifications & 7 & Ohio & City of Columbus - John Gallagher & (614) 645-3970 \\
\hline Use CB Radio to warn truckers to slow down in advance of work areas & & Pennsylvania & $\begin{array}{l}\text { Penn DOT - Richard J. Sesny } \\
\text { FHWA - Michael J. Castellano }\end{array}$ & $\begin{array}{l}(717) 783-6080 \\
(717) 221-4517\end{array}$ \\
\hline Work Zone Advisory Brochure & & Pennsylvania & $\begin{array}{l}\text { Penn DOT - Richard J. Sesny } \\
\text { FHWA - Michael J. Castellano }\end{array}$ & $\begin{array}{l}(717) 783-6080 \\
(717) 221-4517\end{array}$ \\
\hline Place mats with work zone safety information given to restaurants and truck stops along Interstate routes & 2 & Pennsylvania & $\begin{array}{l}\text { Penn DOT - Richard J. Sesny } \\
\text { FHWA - Michael J. Castellano }\end{array}$ & $\begin{array}{l}(717) 783-6080 \\
(717) 221-4517\end{array}$ \\
\hline $\begin{array}{l}\text { Extensive media campaign for I- } 15 \text { project--real-time traffic information to public via } 800 \text { telephone lines, } \\
\text { Website, faxes, mailings, and public meetings }\end{array}$ & & Utah & $\begin{array}{l}\text { FHWA - Jeff Kolb } \\
\text { UDOT - John Leonard }\end{array}$ & $\begin{array}{l}(801) \text { 963-0078 Ext } 232 \\
(801) 594-6236\end{array}$ \\
\hline Dissemination of information on current work zones through the trucking associations & & Utah & $\begin{array}{l}\text { FHWA - Robert Kelleher } \\
\text { UMTA - Terry Smith }\end{array}$ & $\begin{array}{l}(801) 963-0096 \text { Ext } 247 \\
(801) 973-9370\end{array}$ \\
\hline Weekend closure of I-405 for resurfacing & $1-7$ & Washington & $\begin{array}{l}\text { WSDOT - Kim Henry } \\
\text { WSDOT - Arnie Korynta }\end{array}$ & 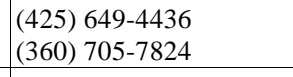 \\
\hline Traffic Safety Information Center & & Region 10 & FHWA - Tracey Lewellyn-Barnett & (503) 399-5775 \\
\hline \multicolumn{5}{|l|}{ Category \# 9 - Enforcement } \\
\hline Construction Zone Enhanced Enforcement Program and MaintenancZone Enhanced Enforcement Program & & California & $\begin{array}{l}\text { Caltrans - James Rogers } \\
\text { Caltrans- Jack Carr }\end{array}$ & $\begin{array}{l}(916) 459-5245 \\
(916) 654-5627\end{array}$ \\
\hline Use of active law enforcement services to control speed in work zones & & Florida & $\begin{array}{l}\text { FHWA - Bobby Norburn } \\
\text { FDOT- Charles Goodman }\end{array}$ & $\begin{array}{l}(850) 942-9578 \\
(850) 414-4150\end{array}$ \\
\hline Full-time State Police Liaison Officer assigned to the State Highway Administration & & Maryland & $\begin{array}{l}\text { MSP - Lt. C. D. Tyler } \\
\text { MdSHA - Wayne Styles }\end{array}$ & 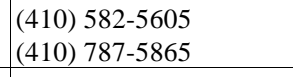 \\
\hline Evaluation of Project $A D V A N C E$ (Aggressive Driving Video and Non-Contact Enforcement) & 10 & Maryland & MSP - TFC M. Almond & (410) 694-6100 \\
\hline $\begin{array}{l}\text { Dedicated (full time) New Jersey State Police Construction Unit assigned to New Jersey DOT construction } \\
\text { projects }\end{array}$ & & New Jersey & $\begin{array}{l}\text { FHWA - Gene Amparano } \\
\text { NJDOT - Michael W. Gross } \\
\text { NJSP - Lt. Donna Dooner }\end{array}$ & $\begin{array}{l}(609) 637-4234 \\
(609) 530-5500 \\
(609) 883-0247\end{array}$ \\
\hline Drone radar in work zones & 10 & Massachusetts & $\begin{array}{l}\text { MHD - Charles F. Sterling } \\
\text { FHWA - Mike Graf }\end{array}$ & $\begin{array}{l}(617) 973-7360 \\
(617) 494-3359 \\
\end{array}$ \\
\hline State Police hired by the contractor & $6-7$ & Oklahoma & $\begin{array}{l}\text { FHWA - Deanna Mills } \\
\text { ODOT - Veldo Goins }\end{array}$ & 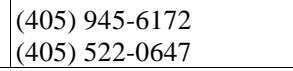 \\
\hline
\end{tabular}




\begin{tabular}{|c|c|c|c|c|}
\hline PRACTICE & $\begin{array}{l}\text { CATEGORY } \\
\text { CROSS } \\
\text { REFERENCE }\end{array}$ & $\begin{array}{c}\text { STATE / } \\
\text { FHWA Region }\end{array}$ & CONTACT PEOPLE & TELEPHONE \\
\hline Periodic meetings with State Police to discuss work zone issues & 2 & Pennsylvania & $\begin{array}{l}\text { Penn DOT - Richard J. Sesny } \\
\text { FHWA - Michael J. Castellano }\end{array}$ & $\begin{array}{l}\text { (717) } 783-6080 \\
\text { (717) } 221-4517\end{array}$ \\
\hline State Police hired by the contractor on the I-15 project & & Utah & $\begin{array}{l}\text { FHWA - Robert Kelleher } \\
\text { UHP - Sgt. Danny Catlin }\end{array}$ & $\begin{array}{l}\text { (801) 963-0096 Ext } 247 \\
\text { (801) 965-4676 }\end{array}$ \\
\hline \multicolumn{5}{|l|}{ Category \# 10 - ITS and Innovative Technology } \\
\hline Highway Closure and Restriction System & & Arizona & $\begin{array}{l}\text { FHWA-Phil Bleyl } \\
\text { ADOT-Dottie Shoup }\end{array}$ & $\begin{array}{l}(602) 379-3913 \\
(602) 252-1951\end{array}$ \\
\hline Mobile Surveillance/Ramp Metering via wireless communication systems (This is a field operational test) & & California & Caltrans - Ed Khosravi & (714) $724-2453$ \\
\hline Automated Data Acquisition and Processing of Traffic Information in Real-time & & California & $\begin{array}{l}\text { Caltrans - Harold Jones } \\
\text { Scientex - Ken Knowles }\end{array}$ & 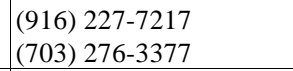 \\
\hline Development of an automated machine for cone placement and retrieval & & California & Caltrans - Juan Araya & (916) 654-8170 \\
\hline Indiana lane merge & 7 & Indiana & INDOT - Dan Shamo & (317) 232-5523 \\
\hline ATIS (Advanced Traveler Information System) or Indiana expert system & 7 & Indiana & INDOT - Dan Shamo & (317) $232-5523$ \\
\hline Portable ITS technology in work zones. & & Indiana & INDOT - Dan Shamo & (317) $232-5523$ \\
\hline Condition-Responsive Work Zone Traffic Control (CRWZTC) System & & Maryland & MdSHA - Jean Yves Point-du-Jour & (410) $787-5866$ \\
\hline Evaluation of ADDCO's Advanced Portable CCTV System & & Maryland & MdSHA - Jean Yves Point-du-Jour & (410) $787-5866$ \\
\hline Portable Traffic Management System - Smart Work Zone & & Minnesota & MnDOT - Michael Kowski & (651) 582-1068 \\
\hline “Orion” (Traffic map/video in parking garages) & 8 & Minnesota & $\begin{array}{l}\text { MnDOT - James Wright } \\
\text { FHWA - James McCarthy }\end{array}$ & $\begin{array}{l}\text { (651) } 582-1349 \\
\text { (651) } 291-6112\end{array}$ \\
\hline “Trilogy” (In vehicle guidance) & & Minnesota & $\begin{array}{l}\text { MnDOT - Steve Bahler } \\
\text { FHWA - James McCarthy }\end{array}$ & $\begin{array}{l}(651) 296-0152 \\
(651) 291-6112 \\
\end{array}$ \\
\hline Portable ITS technology in work zones & & Missouri & $\begin{array}{l}\text { MoDOT - Tom Ryan } \\
\text { FHWA - Bob Thomas }\end{array}$ & $\begin{array}{l}(573) 526-0117 \\
(573) 636-7104\end{array}$ \\
\hline Use of 42 " flexible cones (a.k.a. "Grabber Cones") & & Ohio & $\begin{array}{l}\text { ODOT - Mack Braxton } \\
\text { FHWA- Joe Glinski }\end{array}$ & $\begin{array}{l}(614) 752-8829 \\
(614) 280-6876\end{array}$ \\
\hline Evaluation of Portable Traffic Management System & & Pennsylvania & $\begin{array}{l}\text { Penn DOT - Richard J. Sesny } \\
\text { FHWA - Michael J. Castellano }\end{array}$ & $\begin{array}{l}\text { (717) } 783-6080 \\
(717) 221-4517\end{array}$ \\
\hline \multicolumn{5}{|l|}{ Category \# 11 - Evaluation and Feedback } \\
\hline Research Project entitled "Effective Countermeasures to Reduce Accidents in Work Zones" & & Arizona & $\begin{array}{l}\text { FHWA - Phil Bleyl } \\
\text { ADOT - Frank McCullagh } \\
\text { ASU - Dr. Jonathan Upchurch }\end{array}$ & $\begin{array}{l}(602) 379-3913 \\
(602) 256-6367 \\
(602) 965-1713\end{array}$ \\
\hline Traffic/Through Construction Workgroup & & Arizona & $\begin{array}{l}\text { FHWA - Phil Bleyl } \\
\text { ADOT- Paul Hurst } \\
\text { ADOT- Curt Litin }\end{array}$ & $\begin{array}{l}(602) 379-3913 \\
(602) 255-8544 \\
(602) 255-8687\end{array}$ \\
\hline $\begin{array}{l}\text { City organized consultant and contractor Quality Improvement Team to recommend ways to build projects } \\
\text { quicker, better, cheaper and safer. Peer review by other cities }\end{array}$ & & Arizona & $\begin{array}{l}\text { FHWA - Phil Bleyl } \\
\text { City of Phoenix - Jim Sparks }\end{array}$ & $\begin{array}{l}(602) \\
(602)\end{array} 262-49135$ \\
\hline Baseline of accidents in the work zone & & California & FHWA - R. C. Slovensky & (916) 498-5774 \\
\hline Involvement of the Colorado Contractor's Association in annual work zone traffic control reviews & & Colorado & $\begin{array}{l}\text { CCA - Eldon Strong } \\
\text { CDOT - John Ward }\end{array}$ & $\begin{array}{l}(303) 290-6611 \\
(303) 757-9249\end{array}$ \\
\hline
\end{tabular}




\begin{tabular}{|c|c|c|c|c|}
\hline PRACTICE & $\begin{array}{l}\text { CATEGORY } \\
\text { CROSS } \\
\text { REFERENCE }\end{array}$ & $\begin{array}{c}\text { STATE / } \\
\text { FHWA Region }\end{array}$ & CONTACT PEOPLE & TELEPHONE \\
\hline Maintenance of Traffic Committee & $1-7$ & Florida & $\begin{array}{l}\text { FHWA - Bobby Norburn } \\
\text { FDOT - Alan Lafferty }\end{array}$ & 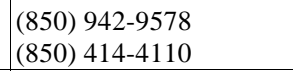 \\
\hline Analysis of truck drivers' opinions on safety and traffic control on highway work zones & & Illinois & $\begin{array}{l}\text { IDOT - Dennis Whitehead } \\
\text { FHWA - Russ Jorgenson }\end{array}$ & $\begin{array}{l}(217) 782-3466 \\
(217) 492-4630\end{array}$ \\
\hline Total Quality Management Utility Relocation Team & & Illinois & $\begin{array}{l}\text { IDOT - John Bellis } \\
\text { FHWA - Peter Hartman }\end{array}$ & $\begin{array}{l}(217) 782-3408 \\
(217) 492-4622\end{array}$ \\
\hline Evaluation of traffic management plans (successes and failures) after the project is complete & & Indiana & $\begin{array}{l}\text { FHWA - Ed Ratulowski } \\
\text { INDOT - David Boruff }\end{array}$ & $\begin{array}{l}(317) 226-7342 \\
(317) 232-5222\end{array}$ \\
\hline Maintenance of Traffic Task Force & & Maryland & MdSHA - Wayne Styles & (410) $787-5865$ \\
\hline Analysis of work zone crash data & & New York & NYSDOT - Jim Bryden & (518) 485-1834 \\
\hline Statewide Work Zone Inspection Program & & New York & NYSDOT - Jim Bryden & (518) 485-1834 \\
\hline Annual customer survey on effectiveness of traffic through work zones & & Ohio & City of Columbus - John Gallagher & (614) 645-3970 \\
\hline Customer survey for work zones & & Pennsylvania & $\begin{array}{l}\text { Penn DOT - Richard J. Sesny } \\
\text { FHWA - Michael J. Castellano }\end{array}$ & $\begin{array}{l}(717) 783-6080 \\
(717) 221-4517\end{array}$ \\
\hline Work Zone Quality Assurance Review & & Pennsylvania & $\begin{array}{l}\text { Penn DOT - Richard J. Sesny } \\
\text { FHWA - Michael J. Castellano }\end{array}$ & $\begin{array}{l}(717) 783-6080 \\
(717) 221-4517\end{array}$ \\
\hline Crash testing of work zone devices & & Texas & TxDOT - Greg Brinkmeyer & (512) 416-3120 \\
\hline Research project on lighting configurations of work zone devices and equipment & & Texas & TxDOT - Greg Brinkmeyer & (512) 416-3120 \\
\hline Human factors project on motorist reaction to work zones & & Texas & TxDOT - Greg Brinkmeyer & (512) 416-3120 \\
\hline $\begin{array}{l}\text { Achievement--No work zone fatalities in } 1996 \text { and no work zone fatalities involving commercial vehicles in the } \\
\text { past } 5 \text { years }\end{array}$ & & Utah & $\begin{array}{l}\text { UDOT - Glenn Schulte } \\
\text { FHWA - Martin Knopp }\end{array}$ & $\begin{array}{l}(801) 965-4376 \\
(801) 963-0078 \text { Ext } 236\end{array}$ \\
\hline $\begin{array}{l}\text { Project specific customer surveys on I-15 project to evaluate the effectiveness of minimizing delays and } \\
\text { enhancing the safety of work zones }\end{array}$ & & Utah & UDOT - Lindsey Ferrari & (801) 594-6326 \\
\hline Study - "Effectiveness of Unmanned Radar - A Speed Control Technique in Freeway Work Zones" & & Virginia & $\begin{array}{l}\text { FHWA - Robert F. McCarty } \\
\text { VDOT - David Rush }\end{array}$ & $\begin{array}{l}(804) \\
281-5109 \\
(804) 371-6672\end{array}$ \\
\hline $\begin{array}{l}\text { Research Study - "Effectiveness of Changeable Message Signs (CMS) in Controlling Vehicle Speeds in Work } \\
\text { Zones-Phase II" }\end{array}$ & & Virginia & $\begin{array}{l}\text { FHWA - Robert F. McCarty } \\
\text { VDOT - Nicholas J. Garber }\end{array}$ & $\begin{array}{l}(804) 281-5109 \\
(804) 293-1908\end{array}$ \\
\hline Work Zone Safety Task Force & & Washington & WSDOT - John F. Conrad & (360) 705-7801 \\
\hline Analysis of work zone crash data & & Wyoming & $\begin{array}{l}\text { WYDOT - Anthony (Bud) Schepp } \\
\text { FHWA - Larry Swanson }\end{array}$ & $\begin{array}{l}(307) 777-4491 \\
(307) 772-2004 \text { Ext } 47\end{array}$ \\
\hline Study - "Road Construction Safety Audit Procedure" (University of Wyoming) & & Wyoming & $\begin{array}{l}\text { WYDOT - Anthony (Bud) Schepp } \\
\text { FHWA - Larry Swanson } \\
\text { Univ of Wyoming - Dr. Eugene } \\
\text { Wilson }\end{array}$ & $\begin{array}{l}\text { (307) 777-4491 } \\
\text { (307) 772-2004 Ext } 47 \\
(307) 766-6743\end{array}$ \\
\hline
\end{tabular}

Additional information on each of these Best Policies/Practices can be found on FHWA's Quality Homepage [http://www.fhwa.dot.gov/quality/bestprac.htm] 


\section{APPENDIX "B"}




\section{APPENDIX 'B"}

\section{TRANSPORTATION AGENCIES, ASSOCIATIONS, ORGANIZATIONS AND INDUSTRIES PARTICIPATING IN THE REVIEW}

\begin{tabular}{|c|c|}
\hline AGENCY & ADDRESS \\
\hline 3 M Corporation & $\begin{array}{l}3 \text { M Center I - } 94 \text { \& Mc Knight Road } \\
\text { St Paul, Minnesota 55144-1000 } \\
\text { Telephone: (612) 733-1110 }\end{array}$ \\
\hline AAA Safety Research Foundation & $\begin{array}{l}1440 \text { New York Avenue, NW } \\
\text { Washington, D.C. } 20005 \\
\text { Telephone: (202) 638-5944 }\end{array}$ \\
\hline Addco & $\begin{array}{l}240 \text { Arlington Ave East } \\
\text { St Paul, Minnesota } 55117-3908 \\
\text { Telephone: (612) 558-3517 }\end{array}$ \\
\hline $\begin{array}{l}\text { American Concrete Paving Association } \\
\text { Oklahoma - Arkansas Chapter }\end{array}$ & $\begin{array}{l}429 \text { N.E. 50th Street } \\
\text { Oklahoma City, Oklahoma } \\
\text { Telephone: (405) 525-7500 }\end{array}$ \\
\hline $\begin{array}{l}\text { American Highway Users Alliance } \\
\text { (HUFSAM) }\end{array}$ & $\begin{array}{l}1776 \text { Massachusetts Avenue, N.W.; Suite } \\
500 \\
\text { Washington, DC } 20036 \\
\text { Telephone: (202) } 857-1200\end{array}$ \\
\hline $\begin{array}{l}\text { American Road \& Transportation } \\
\text { Builders Association }\end{array}$ & $\begin{array}{l}1010 \text { Massachusetts Ave., NW } \\
\text { Washington, DC } 20001 \\
\text { Telephone: (202) 289-4434 }\end{array}$ \\
\hline $\begin{array}{l}\text { American Traffic Safety Services } \\
\text { Association }\end{array}$ & $\begin{array}{l}5440 \text { Jefferson Davis Highway } \\
\text { Fredericksburg, Virginia } 22407 \\
\text { Telephone: (540) } 898-5400\end{array}$ \\
\hline American Trucking Associations & $\begin{array}{l}2200 \text { Mill Road } \\
\text { Alexandria, Virginia 22314-4677 } \\
\text { Telephone: (703) 838-1847 }\end{array}$ \\
\hline
\end{tabular}

\begin{tabular}{|c|c|}
\hline AGENCY & ADDRESS \\
\hline APAC - Oklahoma, Inc. & $\begin{array}{l}\text { P.O. Box } 580670 \\
\text { Tulsa, Oklahoma } \\
\text { Telephone: (918) 438-2020 }\end{array}$ \\
\hline Arizona Department of Transportation & $\begin{array}{l}206 \text { South 17th Avenue } \\
\text { Phoenix, Arizona } 85007 \\
\text { Telephone: (602) 255-7011 }\end{array}$ \\
\hline $\begin{array}{l}\text { Associated General Contractors of } \\
\text { Illinois }\end{array}$ & $\begin{array}{l}3219 \text { Executive Park Drive } \\
\text { Springfield, Illinois } 62708 \\
\text { Telephone: (217) } 789-2650\end{array}$ \\
\hline Barrier Systems Inc. & $\begin{array}{l}100 \text { William Street \#206 } \\
\text { Carson City, Nevada 89701-3104 } \\
\text { Telephone: (702) 885-2598 }\end{array}$ \\
\hline $\begin{array}{l}\text { California Department of } \\
\text { Transportation }\end{array}$ & $\begin{array}{l}\text { P.O. Box } 942873 \\
\text { Sacramento, California } 94273-0001 \\
\text { Telephone: (916) 654-5266 }\end{array}$ \\
\hline $\begin{array}{l}\text { City of Chicago } \\
\text { Department of Transportation }\end{array}$ & $\begin{array}{l}30 \text { North LaSalle Street,; Suite } 500 \\
\text { Chicago, Illinois } 60602-2570 \\
\text { Telephone: (312) } 744-4536\end{array}$ \\
\hline $\begin{array}{l}\text { City of Columbus } \\
\text { Public Service Department }\end{array}$ & $\begin{array}{l}90 \text { W. Broad Street ; Room } 301 \\
\text { Columbus, Ohio 43215-9009 } \\
\text { Telephone: (614) 645-7860 }\end{array}$ \\
\hline $\begin{array}{l}\text { City of Los Angeles } \\
\text { Department of Transportation }\end{array}$ & $\begin{array}{l}205 \text { S. Broadway; Suite } 300 \\
\text { Los Angeles, California } \\
\text { Telephone: (213) 485-5681 }\end{array}$ \\
\hline
\end{tabular}




\begin{tabular}{|c|c|}
\hline $\begin{array}{l}\text { City of Phoenix } \\
\text { Street Transportation Department }\end{array}$ & $\begin{array}{l}200 \text { W. Washington; 5th Floor } \\
\text { Phoenix, Arizona 85003 } \\
\text { Telephone: (602) 262-6136 }\end{array}$ \\
\hline Clements \& Associates & $\begin{array}{l}11109 \text { Colechester Court } \\
\text { Yukon, Oklahoma } 73099 \\
\text { Telephone: (405) 373-2225 }\end{array}$ \\
\hline CMI Corporation & $\begin{array}{l}\text { P.O. Box } 1985 \\
\text { Oklahoma City, Oklahoma } 73101 \\
\text { Telephone: (405) 491-2088 }\end{array}$ \\
\hline $\begin{array}{l}\text { Cobb County - Georgia } \\
\text { Department of Transportation }\end{array}$ & $\begin{array}{l}100 \text { Cherokee Street; Suite } 150 \\
\text { Marietta, Georgia 30090 } \\
\text { Telephone: (770) 528-1608 }\end{array}$ \\
\hline Colorado - AAA & $\begin{array}{l}4100 \text { E. Arkansas Avenue } \\
\text { Denver, Colorado } 80222 \text { - } 3491 \\
\text { Telephone: (303) 753-8800 }\end{array}$ \\
\hline Colorado Contractors Association, Inc. & $\begin{array}{l}6880 \text { S. Yosemite Ct.; Suite } 200 \\
\text { Englewood, Colorado } 801255 \text { - } 3489 \\
\text { Telephone: (303) 290-6611 }\end{array}$ \\
\hline Colorado Department of Transportation & $\begin{array}{l}4201 \text { East Arkansas Avenue } \\
\text { Denver, Colorado } 80222 \\
\text { Telephone: (303) 757-9011 }\end{array}$ \\
\hline Commercial Vehicle Safety Alliance & $\begin{array}{l}5430 \text { Grosvnor Lane; Suite } 130 \\
\text { Bethesda, Maryland } 20814 \\
\text { Telephone: (301) 564-1623 }\end{array}$ \\
\hline Construction Innovation Forum & $\begin{array}{l}350 \text { South Main Street; Suite } 350 \\
\text { Ann Arbor, Michigan 48104-2131 }\end{array}$ \\
\hline CTE Engineers & $\begin{array}{l}303 \text { E. Wacker Drive; Suite } 600 \\
\text { Chicago, Illinois 60601-5212 } \\
\text { Telephone: (312) 938-0300 }\end{array}$ \\
\hline Duit Construction Co., Inc. & $\begin{array}{l}5860 \text { Industrial Blvd. } \\
\text { Edmond, Oklahoma } \\
\text { Telephone: (405) 340-6026 }\end{array}$ \\
\hline Flasher Companies & $\begin{array}{l}2360 \text { South } 3270 \text { West } \\
\text { Salt Lake City, Utah } 84119 \\
\text { Telephone: (801) 972-4474 }\end{array}$ \\
\hline
\end{tabular}

\begin{tabular}{|c|c|}
\hline Flasher Company & $\begin{array}{l}520 \text { N. Virginia Avenue } \\
\text { Oklahoma City, Oklahoma } 73106 \\
\text { Telephone: (405) 232-3414 }\end{array}$ \\
\hline Flexible Pavements Incorporated & $\begin{array}{l}37 \text { W. Broad Street } \\
\text { P.O. Box } 16186 \\
\text { Columbus, OH } 43216 \\
\text { Telephone: (614) 221-5402 }\end{array}$ \\
\hline Florida Department of Transportation & $\begin{array}{l}\text { Haydon Burns Building } \\
605 \text { Suwannee Street } \\
\text { Tallahassee, Florida } 32301 \\
\text { Telephone: (904) 488-8541 }\end{array}$ \\
\hline Florida Turnpike District & $\begin{array}{l}\text { P. O. Box } 9828 \\
\text { Ft. Lauderdale, Florida } 33310 \\
\text { Telephone: (954) 975-4855 }\end{array}$ \\
\hline Georgia Department of Transportation & $\begin{array}{l}\text { No. } 2 \text { Capitol Square } \\
\text { Atlanta, Georgia } 30334 \\
\text { Telephone: (404) 656-5200 }\end{array}$ \\
\hline Haskell Lemon Construction Company & $\begin{array}{l}\text { P.O. Box } 75608 \\
\text { Oklahoma City, Oklahoma } \\
\text { Telephone: (405) 947-6069 }\end{array}$ \\
\hline Herlihy Mid-Continent Company & $\begin{array}{l}1306 \text { Marquette Drive } \\
\text { Romeoville, Illinois 60446-1026 } \\
\text { Telephone: (630) 378-1000 }\end{array}$ \\
\hline Illinois Department of Transportation & $\begin{array}{l}2300 \text { South Dirksen Parkway } \\
\text { Springfield, Illinois } 62764 \\
\text { Telephone: (217) 782-2632 }\end{array}$ \\
\hline Illinois Road Builders Association & $\begin{array}{l}500 \text { Park Boulevard; Suite } 1250 \\
\text { Itasca, Illinois } 60143 \\
\text { Telephone: (630) 773-1220 }\end{array}$ \\
\hline Illinois State Toll Highway Authority & $\begin{array}{l}\text { One Authority Drive } \\
\text { Downers Grove, Illinois } 60515 \\
\text { Telephone: (630) 241-6800 }\end{array}$ \\
\hline Indiana Department of Transportation & $\begin{array}{l}100 \text { North Senate Avenue; } \\
\text { Indianapolis, Indiana } 46204 \\
\text { Telephone: (317) 232-5526 }\end{array}$ \\
\hline
\end{tabular}




\begin{tabular}{|c|c|}
\hline $\begin{array}{l}\text { International Brotherhood of Teamsters } \\
\text { Safety and Health Department }\end{array}$ & $\begin{array}{l}25 \text { Louisiana Avenue, N.W. } \\
\text { Washington, DC 20001 } \\
\text { Telephone: (202) 624-6830 }\end{array}$ \\
\hline $\begin{array}{l}\text { International Union of Operating } \\
\text { Engineers }\end{array}$ & $\begin{array}{l}1125 \text { 17th Street, N.W. } \\
\text { Washington, D.C. } 20036 \\
\text { Telephone: (202) } 429-9100\end{array}$ \\
\hline Iowa Department of Transportation & $\begin{array}{l}800 \text { Lincoln Way } \\
\text { Ames, Iowa 50010 } \\
\text { Telephone: (515) 239-1101 }\end{array}$ \\
\hline ITS America & $\begin{array}{l}400 \text { Virginia Avenue, S.W. ; Suite } 800 \\
\text { Washington, DC } 20024 \\
\text { Telephone: (202) } 484-4540\end{array}$ \\
\hline $\begin{array}{l}\text { Maricopa County - Arizona } \\
\text { Department of Transportation }\end{array}$ & $\begin{array}{l}2901 \text { W. Durango Street } \\
\text { Phoenix, Arizona } 85009 \\
\text { Telephone: (602) 506-8668 }\end{array}$ \\
\hline $\begin{array}{l}\text { Maryland State Highway } \\
\text { Administration }\end{array}$ & $\begin{array}{l}\text { P.O. Box } 717 \\
\text { Baltimore, Maryland } 21203 \\
\text { Telephone: (410) 545-0302 }\end{array}$ \\
\hline Maryland State Police & $\begin{array}{l}7491 \text { Connelley Drive } \\
\text { Hanover, Maryland } 21076\end{array}$ \\
\hline Massachusetts Highway Department & $\begin{array}{l}\text { Transportation Building } \\
\text { 10 Park Plaza, Room } 3140 \\
\text { Boston, Massachusetts } 02116-3973 \\
\text { Telephone: (617) 973-7800 }\end{array}$ \\
\hline Michigan Department of Transportation & $\begin{array}{l}425 \text { West Ottawa } \\
\text { P.O. Box } 30050 \\
\text { Lansing, Michigan } 48909 \\
\text { Telephone: (517) 373-2090 }\end{array}$ \\
\hline $\begin{array}{l}\text { Minnesota Department of } \\
\text { Transportation }\end{array}$ & $\begin{array}{l}\text { State Transportation Building } \\
\text { St. Paul, Minnesota 55155 } \\
\text { Telephone: (612) 297-3000 }\end{array}$ \\
\hline Missouri Department of Transportation & $\begin{array}{l}\text { P.O. Box } 270 \\
\text { Jefferson City, Missouri } 65102 \\
\text { Telephone: (573) 751-2551 }\end{array}$ \\
\hline
\end{tabular}

\begin{tabular}{|c|c|}
\hline $\begin{array}{l}\text { Mississippi Department of } \\
\text { Transportation }\end{array}$ & $\begin{array}{l}\text { P.O. Box } 1850 \\
\text { Jackson, Mississippi 39215-1850 } \\
\text { Telephone: (601) 359-7001 }\end{array}$ \\
\hline $\begin{array}{l}\text { New Jersey Department of } \\
\text { Transportation }\end{array}$ & $\begin{array}{l}1035 \text { Parkway Avenue } \\
\text { Trenton, New Jersey } 08625 \\
\text { Telephone: (609) 530-2001 }\end{array}$ \\
\hline New Jersey State Police & $\begin{array}{l}\text { P.O. Box } 7068 \\
\text { W. Trenton, New Jersey } 08625 \\
\text { Telephone: (609) 883-0247 }\end{array}$ \\
\hline $\begin{array}{l}\text { New York Department of } \\
\text { Transportation }\end{array}$ & $\begin{array}{l}1220 \text { Washington Avenue } \\
\text { State Campus, Bldg. } 5 \\
\text { Albany, New York } 12232 \\
\text { Telephone: (518) 457-4422 }\end{array}$ \\
\hline New York Thruway Authority & $\begin{array}{l}200 \text { Southern Blvd. } \\
\text { Albany, New York } 12209 \\
\text { Telephone: (518) 471-4453 }\end{array}$ \\
\hline $\begin{array}{l}\text { North Carolina Department of } \\
\text { Transportation }\end{array}$ & $\begin{array}{l}\text { P.O. Box } 25201 \\
\text { Raleigh, North Carolina } 27611 \\
\text { Telephone: (919) 733-2520 }\end{array}$ \\
\hline $\begin{array}{l}\text { North Carolina - Governor's Highway } \\
\text { Safety Program Office }\end{array}$ & $\begin{array}{l}215 \text { E. Lane Street } \\
\text { Raleigh, North Carolina } 27601 \\
\text { Telephone: (919) 733-3083 }\end{array}$ \\
\hline North Carolina Trucking Association & $\begin{array}{l}\text { P. O. Box } 2977 \\
\text { Raleigh, North Carolina } 27602 \\
\text { Telephone: (919) 834-0387 }\end{array}$ \\
\hline Ohio Department of Transportation & $\begin{array}{l}25 \text { S. Front Street } \\
\text { Columbus, Ohio } 43215 \\
\text { Telephone: (614) 466-2335 }\end{array}$ \\
\hline $\begin{array}{l}\text { Oklahoma Department of } \\
\text { Transportation }\end{array}$ & $\begin{array}{l}200 \text { N.E. 21st Street } \\
\text { Oklahoma City, Oklahoma } 73105 \\
\text { Telephone: (405) 521-2631 }\end{array}$ \\
\hline Oregon Department of Transportation & $\begin{array}{l}\text { State Transportation Building } \\
\text { Salem, Oregon } 97310 \\
\text { Telephone: (503) 986-3200 }\end{array}$ \\
\hline
\end{tabular}




\begin{tabular}{|c|c|}
\hline $\begin{array}{l}\text { Owner Operator Independent Drivers } \\
\text { Association }\end{array}$ & $\begin{array}{l}1101 \text { 30th Street, N.W.; Suite } 300 \\
\text { Washington, D.C. } 20007 \\
\text { Telephone: (202) } 944-8600\end{array}$ \\
\hline $\begin{array}{l}\text { Pennsylvania Department of } \\
\text { Transportation }\end{array}$ & $\begin{array}{l}555 \text { Walnut Street } \\
\text { Harrisburg, Pennsylvania 17101-1900 } \\
\text { (717) 787-5574 }\end{array}$ \\
\hline Pennsylvania Motor Truck Association & $\begin{array}{l}910 \text { Linda Lane } \\
\text { Camp Hill, Pennsylvania 17011-6409 } \\
\text { Telephone: (717) 761-7122 }\end{array}$ \\
\hline Pennsylvania Turnpike Commission & $\begin{array}{l}\text { P.O. Box } 67676 \\
\text { Harrisburg, Pennsylvania 17106-7676 } \\
\text { Telephone: (717) 939-9551 }\end{array}$ \\
\hline Roadway Safety Foundation & $\begin{array}{l}1776 \text { Massachusetts Avenue, N.W.; Suite } \\
500 \\
\text { Washington, DC } 20036 \\
\text { Telephone: (202) } 857-1200\end{array}$ \\
\hline Richmond Metropolitan Authority & $\begin{array}{l}901 \text { E. Byrd Street; Suite } 1110 \\
\text { Richmond, Virginia } 23219 \\
\text { Telephone: (804) 649-8494 }\end{array}$ \\
\hline Texas Department of Transportation & $\begin{array}{l}\text { Dewitt C. Greer Building } \\
\text { 11th and Brazos Streets } \\
\text { Austin, Texas 78701-2483 } \\
\text { Telephone: (512) 463-8585 }\end{array}$ \\
\hline The Road Information Program (TRIP) & $\begin{array}{l}1200 \text { 18th Street, N.W.; Suite } 314 \\
\text { Washington, DC } 20036 \\
\text { Telephone: (202) 466-6706 }\end{array}$ \\
\hline The Scientex Corporation & $\begin{array}{l}1655 \text { North Fort Myer Drive; Suite } 400 \\
\text { Arlington, Virginia } 22209 \\
\text { Telephone: (703) 256-3377 }\end{array}$ \\
\hline Tri-Mack Barricade Company & $\begin{array}{l}\text { P.O. Box } 31230 \\
\text { Indianapolis, IN } 46231 \\
\text { Telephone: (317) 240-0835 }\end{array}$ \\
\hline
\end{tabular}

\begin{tabular}{|c|c|}
\hline Utah Associated General Contractors & $\begin{array}{l}1135 \text { South W. Temple } \\
\text { Salt Lake city, Utah } 84101 \\
\text { Telephone: (801) 532-6588 }\end{array}$ \\
\hline Utah Department of Transportation & $\begin{array}{l}4501 \text { South } 2700 \text { West } \\
\text { Salt Lake City, Utah } 84119 \\
\text { Telephone: (801) 965-4113 }\end{array}$ \\
\hline Utah Highway Patrol & $\begin{array}{l}5500 \text { W. Amelia Earhart Drive } \\
\text { Admiral Byrd Plaza; Suite } 220 \\
\text { Salt Lake city, Utah } 84116 \\
\text { Telephone: (801) 596-9248 }\end{array}$ \\
\hline Virginia Department of Transportation & $\begin{array}{l}1221 \text { E. Broad Street } \\
\text { Richmond, Virginia } 23219 \\
\text { Telephone: (804) 786-2702 }\end{array}$ \\
\hline $\begin{array}{l}\text { Virginia Road and Transportation } \\
\text { Builders Association }\end{array}$ & $\begin{array}{l}620 \text { Moorefield Park Drive } \\
\text { Suite } 120 \\
\text { Richmond, Virginia 23236-3692 } \\
\text { Telephone: (804) 330-3312 }\end{array}$ \\
\hline $\begin{array}{l}\text { Washington Department of } \\
\text { Transportation }\end{array}$ & $\begin{array}{l}\text { P.O. Box } 47316 \\
\text { Olympia, Washington } 98504-7316 \\
\text { Telephone: (360) 705-7000 }\end{array}$ \\
\hline WLI Industries & $\begin{array}{l}880 \text { North Addison Road } \\
\text { Villa Park, Illinois } 601181-7050 \\
\text { Telephone: (630) } 932-4600\end{array}$ \\
\hline Wyoming Department of Transportation & $\begin{array}{l}\text { P.O. Box } 1708 \\
\text { Cheyenne, Wyoming 82003-1708 } \\
\text { Telephone: (307) 777-4484 }\end{array}$ \\
\hline
\end{tabular}




\section{APPENDIX "C" PRIMARY GUIDANCE - RESOURCES}

The Intermodal Surface transportation Efficiency Act (ISTEA) of 1991 - Section 1051 and Section 1090

The National Highway System Designation Act of 1995 -Section 358(b)

Code of Federal Regulations Title 23, Part 630 Subpart J

Code of Federal Regulations Title 23, Part 635.121

October 24, 1995 Federal Register - The National Highway Work Zone Safety Program

April 19, 1996 Federal Register-General materials Requirements; Warranty Clauses

Report of the Secretary of Transportation to the United States Congress, "Traffic/Congestion Management During Highway Construction” - September 1992

Fatal Analysis Reporting System - maintained by the National Highway Transportation Safety Administration

General Estimates System - maintained by the National Highway Transportation Safety Administration

"Transportation Management for Major Highway Reconstruction - Proceedings of the National Conference on Corridor Traffic Management for Major Highway Reconstruction Chicago Illinois, September 28-October 1, 1986" - Transportation Research Board - Special Report 212

FHWA TECHNICAL ADVISORY (TA 5080.10) “Incentive/Disincentive (I/D) for Early Completion” dated February 8, 1989

FHWA TECHNICAL ADVISORY (TA 5080.15) “Construction Contract Time Determination Procedures" dated October 11, 1991

The National Quality Initiative Survey - 1995

“Work Zone Safety - Good Practices Report," May 1997; FHWA Joint Memorandum from the Directors of the Offices of Engineering and Highway Safety to Regional Administrators dated June 20, 1997 
“Constructability Review Process for Transportation Facilities” (NCHRP PROJECT 10-42);

Texas Transportation Institute dated December 1996

“Contract Management Techniques for Improving Construction Quality" - The Federal Highway Administration (FHWA-RD-96-067) dated July 1997

1996 Highway Statistics - The Federal Highway Administration dated November 1997

FHWA Memorandum from the Director, Office of Engineering "Special Experimental Project No. 14" dated May 4, 1995

“Urban Roadway Congestion Annual Report" - Texas Transportation Institute (Research Report 1131-8) dated August 1996 


\section{APPENDIX “D”}

\section{ACRONYMS}

! AASHTO--American Association of State Highway and Transportation Officials

! ARTBA--American Road and Transportation Builders Association

! AGC--Association of General Contractors

! CPM--Critical Path Method

! $\quad$ FARS--Fatal Analysis Reporting System

! FHWA--Federal Highway Administration

! I/D--Incentive/Disincentive Clauses

! ITS--Intelligent Transportation Systems

! ISTEA--Intermodal Surface Transportation Efficiency Act of 1991

! MUTCD--Manual on Uniform Traffic Control Devices

! NCHRP--National Cooperative Highway Research Program

! NEPA--National Environmental Policy Act

! NHI--National Highway Institute

! NQI--National Quality Initiative

! NHS--National Highway System

! NHWZSP--National Highway Work Zone Safety Program

! OPQC--Office of Program Quality Coordination

! TCP--Traffic Control Plan

! TMP--Traffic Management Plan

! TEA-21--Transportation Equity Act for the 21st Century

! TRB--Transportation Research Board 
Publication No. FHWA-PR-98-01-A 